\title{
Drug use during pregnancy with focus on antidepressants
}

\section{Emelie Wolgast}



Linköping University Medical Dissertation

No. 1763

Drug use during pregnancy with focus on antidepressants

\section{Emelie Wolgast}

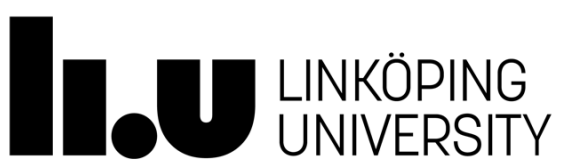

Department of Obstetrics and Gynecology and Department of Biomedical and Clinical Sciences

Linköping University, Linköping, Sweden

Linköping 2020 
$(\mathrm{cc})$ EY-NG NonCommercial 4.0 International License.

https://creativecommons.org/licenses/by-nc/4.0/

Drug use during pregnancy with focus on antidepressants

(C) Emelie Wolgast 2020

Printed by LiU-Tryck, Linköping, Sweden, 2020

ISBN 978-91-7929-750-3

ISSN 0345-0082 


\section{ABSTRACT}

Background: More than half of pregnant women use at least one prescribed medication during pregnancy, and almost all pregnant women use some kind of over-the-counter medication. Depression is one of the most common diseases in the world today, also during the peripartum period. The prevalence of pregnant women using antidepressant medication is increasing. General knowledge about the use of medication during pregnancy needs to improve. The overall aim of the studies on which this thesis is based is therefore to examine different aspects of medication use during pregnancy, with a focus on antidepressants.

Material and methods: Study I was a questionnaire study where 850 pregnant women were asked about their perceptions on medication use during pregnancy. In Study II, plasma samples from 200 women were obtained at gestational weeks 10-12 and 25, and screened for drugs. The results of the analysis were compared with medication use noted in antenatal medical care records. Study III was a national register-based cohort study including 262,329 pregnant women, and their first child born in 2012-2015. Maternal obstetric and neonatal outcomes were studied in three groups: women diagnosed with depression and who had redeemed an antidepressant before becoming pregnant and women who were diagnosed with depression and who had redeemed an antidepressant both before and during pregnancy, were compared with each other and with women who had neither been diagnosed with depression nor been prescribed antidepressants. Study IV was a pharmacokinetic study that included 81 pregnant women with ongoing antidepressant medical treatment. Antidepressant drug and metabolite concentrations were measured throughout pregnancy. Participants were genotyped for enzymes involved in antidepressant drug metabolism, i.e. CYP2D6 and CYP2C19.

Results and conclusions: The majority of pregnant women in our study considered the use of medication during pregnancy as either "probably harmful" or "harmful", and this perception was associated with non-use of medication. The women had high confidence in health care professionals when seeking advice about medication. 
There was a good coherence between reported drug intake in antenatal care records and presence of the drug in the pregnant women's blood. For drugs prescribed for continuous use the coherence was $100 \%$; thus, the reported use of medication in antenatal records is reliable. Women with major depressive disorder and antidepressant medication prior to becoming pregnant were at increased risk for adverse obstetric and neonatal outcomes compared with women without major depressive disorder. Continuation of antidepressant medication during pregnancy somewhat increased the risk of adverse obstetric and neonatal outcomes. The dose-adjusted concentrations of sertraline and citalopram and their metabolites, did not change significantly throughout pregnancy. Observed concentrations of escitalopram, mirtazapine and venlafaxine did not appear to change. 


\section{LIST OF SCIENTIFIC PAPERS}

I. Women's Perceptions of Medication Use during Pregnancy and Breastfeeding - a Swedish cross-sectional questionnaire study

Emelie Wolgast, Lotta Lindh-Åstrand and Caroline Lilliecreutz Acta Obstet Gynecol Scand. 2019;00:1-9.

II. The panorama of drug use in pregnant women by means of drug analytical analyses - a descriptive study

Emelie Wolgast, Ann Josefsson, Martin Josefsson, Caroline Lilliecreutz and Margareta Reis

Eur J Clin Pharmacol. 2018;74: 535-539.

III. The impact of depression and antidepressant medication before and during pregnancy on obstetric and neonatal outcomes; a nationwide population-based study

Emelie Wolgast, Caroline Lilliecreutz, Gunilla Sydsjö, Marie Bladh and Ann Josefsson

Manuscript submitted.

IV. PAPA - Pharmacokinetics of Antidepressant Drugs in PregnAnt Women

Erik Nilzén*, Emelie Wolgast*, Anna-Lena Zackrisson, Ann Josefsson and Margareta Reis. *Equal contribution Manuscript.

The published papers are reprinted by permission of the publishers. 



\section{ABBREVIATIONS}

ADHD attention-deficit/hyperactivity disorder

ATC anatomical, therapeutic, chemical code of a drug

BMQ beliefs about medicines questionnaire

$\mathrm{C}_{\max } \quad$ maximum concentration

CS caesarean section

CYP cytochrome P450

DSM diagnostic and statistical manual of mental disorders

EM extensive metabolizers

EPDS Edinburgh postnatal depression scale

GFR glomerular filtration rate

GW gestational week

ICD international classification of diseases

IM intermediate metabolizers

LBW low birth weight

MAOI monoamine oxidase inhibitor

MBR The Swedish medical birth register

MDD major depressive disorder

NICU neonatal intensive care unit

NPR The Swedish national patient register

OTC over-the-counter

PDR The Swedish prescribed drug register

PIN personal identification numbers

PM poor metabolizer

PNAS poor neonatal adaptation syndrome

PK pharmacokinetic

PTB preterm birth

SD standard deviation

SGA small for gestational age

SNRI serotonin norepinephrine reuptake inhibitors

SSRI selective serotonin reuptake inhibitors

TCA tricyclic antidepressants

TPR The total population register

UM ultrarapid metabolizers 
UHPL-TOF-MS ultra-high performance liquid chromatography with time of flight mass spectrometry

$\mathrm{V}_{\mathrm{D}} \quad$ volume of distribution

VE vacuum extraction

WHO World Health Organization 


\section{CONTENTS}

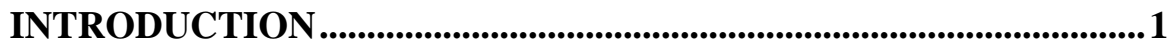

Pregnant women's perceptions about medication................................... 1

Physiologic changes during pregnancy and pharmacokinetics of drugs 2

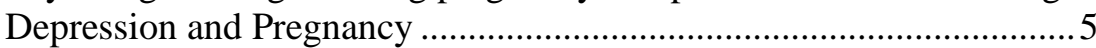

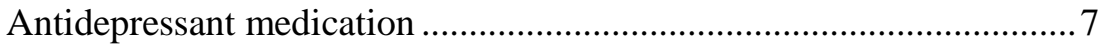

Antidepressant medication during pregnancy ……............................... 8

Depression and risks for adverse maternal and neonatal outcomes.......9

Specific background to the present studies .......................................... 13

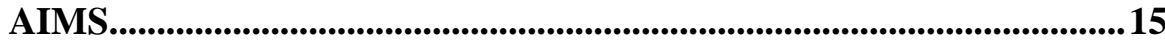

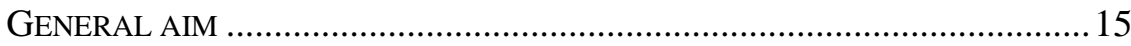

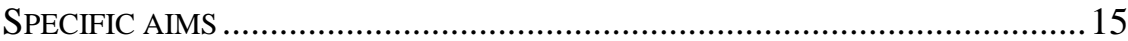

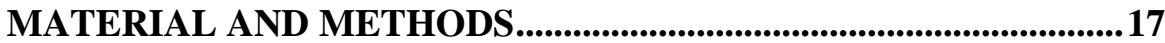

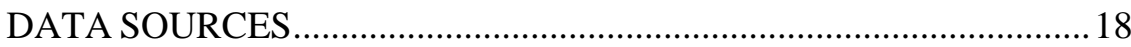

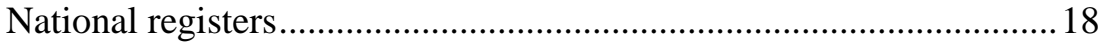

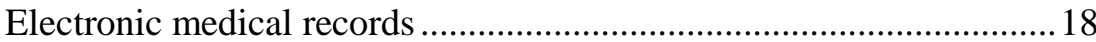

Biobank and maternal blood samples................................................... 19

STUDY POPULATIONS AND STUDY DESIGNS .............................19

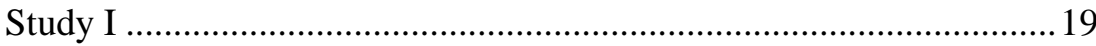

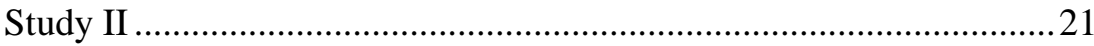

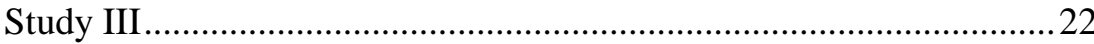

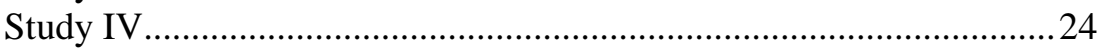

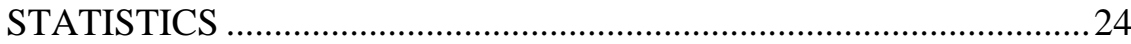

ETHICAL APPROVAL AND CONSIDERATIONS ...........................26

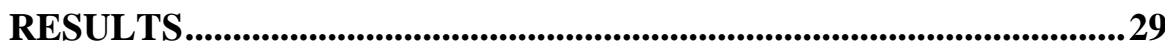

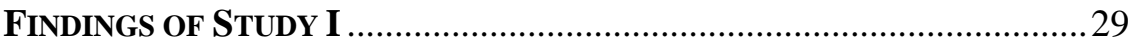

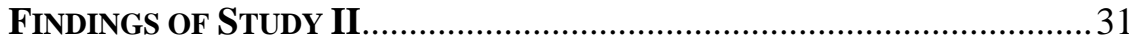

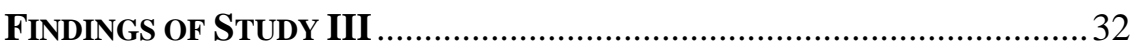

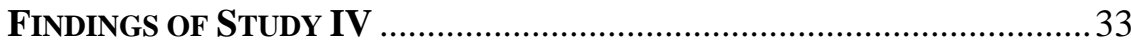

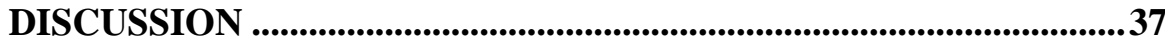

METHODOLOGICAL DISCUSSION ................................................ 37

DISCUSSION OF FINDINGS IN STUDIES I-IV AND CLINICAL

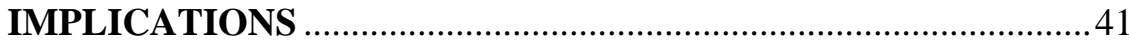

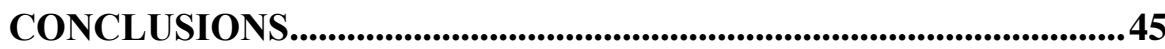

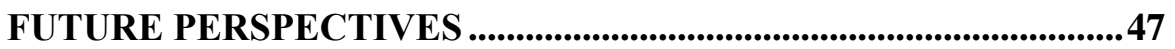


POPULÄRVETENSKAPLIG SAMMANFATTNING............................49

ACKNOWLEDGEMENTS..............................................................53

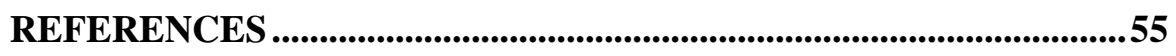

ERRATA ..............................................................................................................65

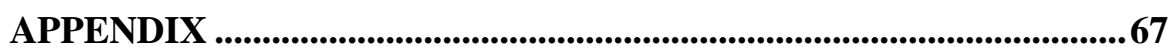




\section{INTRODUCTION}

When treating pregnant women with pharmacological substances consideration has to be given both to the mother and the foetus. The risk of negative effects of the medication for the foetus, and later the child has to be weighed against the benefits of keeping the mother as healthy as possible, taking into account the possible risk of the disease itself on the developing foetus.

Medication use for different kinds of symptoms and conditions during pregnancy is common, even if the woman does not have a chronic disease, and has been increasing throughout the last decades (1). Recent studies have shown that over $95 \%$ of women use medication during their first trimester, both prescribed and over-the-counter (OTC) medication $(2,3)$. Around 60$90 \%$ of the pregnant women use prescription medication (4-8), the most frequently used being antiemetics, antibiotics, paracetamol, antidepressants and thyroid medications (3, 6-8).

For some conditions, i.e. asthma, diabetes, inflammatory bowel disease and systemic lupus erythematosus, pharmacological treatment during pregnancy is essential to avoid the exacerbation of a pre-existing disease and to minimise negative pregnancy, delivery, and neonatal outcomes (9). For example, for pregnant women living with human immunodeficiency virus, adherence to the recommended treatment regimen during pregnancy is important in order to minimise the risk of transmission of the virus to the foetus (10).

\section{Pregnant women's perceptions about medication}

The thalidomide scandal during the 1960s made pregnant women in general hesitant about medication use as well as about advice and information on medication from health care professionals (11). Studies have shown that women often overestimate the teratogenic risk associated with medication in pregnancy and instead potentially risk their own health by avoiding the use of the recommended drug $(12,13)$. Knowledge and beliefs about medication use play an important role in medication adherence among pregnant women (14). Many women avoid using medications during pregnancy, both OTC and prescribed (15), and also avoid using medication to a higher degree 
compared with when they are not pregnant $(15,16)$. Studies have shown that up to one in four women deliberately avoids prescribed medications in pregnancy, most commonly analgesics but also antibiotics (17). The pregnant women's educational level and parity can have an impact on their perceptions of medication use, with less educated women believing that medications in general are more harmful and herbal remedies safe, but the results are diverse $(13,18-21)$. A Danish interview study including pregnant women, has recently shown that professional counselling could lead to less concern about medication use and therefore enhance adherence (22).

\section{Physiologic changes during pregnancy and pharmacokinetics of drugs}

The normal pregnancy and postpartum period is associated with a multitude of physiological, anatomical and biochemical changes that begin immediately post conception, and increase during the course of pregnancy. Some adaptations are secondary to hormonal changes, while others take place to support the pregnant woman and the developing foetus (23). Some of these changes alter the pharmacokinetics (PK) of drugs, and therefore the serum concentrations and the clinical effect of the drugs. PK is the science describing what the body does with the drug; i.e. how the drug is absorbed, distributed metabolised and eliminated from the body. PK data established from studies in men or non-pregnant women cannot be extrapolated to pregnant women as the continuous physiological changes throughout the pregnancy, particularly during the second and the third trimester, affect the PK properties of the drug (Table 1).

Most drugs transfer more or less, through the placenta and consequently, the PK of the woman affects the exposure of the foetus to the drug. Knowledge of pregnancy-induced changes in pharmacokinetics is necessary for allowing eventual adjustments of the drug dosage during pregnancy and thereby achieve an effective treatment and limit maternal and foetal risk (24).

\section{Drug absorption}

Drug absorption is described as the movement of drug from the site of administration into the systemic circulation. Delays or drug loss during absorption may contribute to variation in drug response. Rising progesterone levels during pregnancy reduce gastric emptying and small intestine motility and delay colonic emptying. This may decrease the maximum serum concentration $\left(\mathrm{C}_{\max }\right)$ of a drug, however effects on overall bioavailability are 
small. Gastric $\mathrm{pH}$ is generally increased during pregnancy, which tends to reduce the absorption of weak acids more than that of weak bases. These effects are unlikely to be important during repeated dosing of a drug. The occurrence of nausea and vomiting may lead to low plasma drug concentrations secondary to loss of the drug during vomiting.

Cardiac output and tidal lung volumes increase in pregnancy; this leads to an increased alveolar uptake of medications, and should be considered when administering drugs by inhalation (25).

\section{Drug distribution}

Distribution describes the transfer of a drug between different locations following its entry into the systemic circulation. The volume of distribution $\left(\mathrm{V}_{\mathrm{d}}\right)$ is used to indicate how extensively a systemic dose of medication is dispersed throughout the body. During pregnancy there is an expansion of the intravascular (plasma) volume and extravascular (breast, uterus, peripheral oedema) water content; total body water increases by up to eight litres $(26,27)$. The $V_{d}$ of drugs is often altered during pregnancy due to the increase in plasma volume, particularly for hydrophilic drugs. The increase in $\mathrm{V}_{\mathrm{d}}$ leads to a decrease in $\mathrm{C}_{\max }$ of many drugs.

Body weight typically increases gradually throughout pregnancy, but also continues to rise postpartum in many women. This pregnancy-associated increase in fat stores will result in an increased $V_{d}$ of drugs distributed in fat, and therefore may affect peak drug concentrations (28).

Total plasma concentrations of albumin-bound drugs decrease as a result of haemodilution and a subsequent fall in plasma albumin concentration. The concentration of albumin starts to decrease during the second trimester, and this decrease continues during the third trimester. At the end of the pregnancy plasma albumin can be $70-80 \%$ lower than the prepregnancy value (29). This leads to a decrease in binding to albumin and, therefore, a rise in free (active) drug concentrations of agents that are normally albuminbound. The effects of this is however only clinically significant for very few drugs which are highly protein bound such as epilepsy medications phenytoin and valproic acid. For appropriate dose adjustment, monitoring of plasma concentrations for these drugs is recommended during pregnancy (29). 


\section{Drug metabolism}

Drug metabolism typically results in the formation of a more hydrophilic compound that is then excreted by the liver, kidney, and/or gut. For most drugs, metabolism leads to loss of drug activity. Drug metabolism occurs in many sites in the body, including the liver, intestinal wall, lungs, kidneys, and plasma.

\section{Changes in hepatic drug metabolising activities during pregnancy}

The liver is the primary site of drug metabolism, and the metabolism is mainly catalysed by the cytochrome P450 (CYP) system (30). CYPs are enzymes that play a key role in the metabolism of drugs and other xenobiotics. Genetic polymorphisms lead to pharmacogenetic phenotypes of the CYP enzymes termed as poor metabolizers (PM), intermediate metabolizers (IM), extensive metabolizers (EM), and ultrarapid metabolizers (UM) (31). Polymorphisms influence the metabolism of drugs; UM and EM exhibit lower serum concentrations than the slower genotypes (32), and can thereby affect the efficacy and safety of a drug by either lower or greater exposure to these drugs (33). Some of the hepatic CYP enzymes important in the metabolism of drugs are induced during pregnancy (CYP2B6, CYP2C8, CYP2C9, CYP2D6, CYP2E1, CYP3A4), resulting in increased metabolism and elimination of drugs, whereas other isoenzymes are inhibited (CYP1A2, CYP2C19) leading to impaired elimination $(24,34)$.

\section{Drug elimination}

Renal excretion of drugs is dependent on the glomerular filtration rate (GFR), active tubular secretion and/or reabsorption. During pregnancy renal plasma flow and GFR increase to levels 50-80\% above prepregnancy values. This increase occur shortly after conception, persist throughout the second trimester and reduce slightly in late pregnancy (35). Hence drugs which are eliminated primarily unchanged in the urine, such as penicillin, digoxin and lithium, demonstrate enhanced elimination and lower serum concentrations.

Table 1. Summary of physiologic changes during pregnancy that affects the PK of drugs

$\downarrow$ gastric emptying
$\uparrow$ volume of distribution
$\downarrow$ albumin $\rightarrow \uparrow$ free (active) drug concentration
$\uparrow$ renal elimination




\section{Depression and Pregnancy}

Lifetime prevalence of major depression in women is around $25 \%$ and depression is twice more common in women than in men (36). Women have more severe symptoms and more often experience a co-morbid anxiety compared to men (37). Most women develop their first depression during the reproductive years. The reason for this is not fully understood but pregnancy, miscarriage, infertility etc. as well as socioeconomic, biological, genetic and cultural circumstances may challenge the mental health of women. Depression is a disorder that significantly impairs occupational and/or social functioning and is one of the five leading causes of years lived with disability in the world (38).

The Diagnostic and Statistical Manual of Mental Disorders Fifth Edition (DSM-5) defines perinatal depression as a major depressive episode (MDD) with peripartum onset, i.e. symptom onset during pregnancy or in the four weeks following delivery (39). Diagnostic criteria for MDD are listed in table 2. Another diagnostic system for mental disorders is the International Classification of Diseases (ICD), produced by the WHO. The symptoms chosen for both the ICD-10 and DSM definition of depression are in accordance with the literature (40). For clinical diagnostics of mental disorders in Sweden, the DSM-5 is the most used, whereas the ICD is used to code diagnosis in different registers (41).

Differences in prevalence in different studies could be due to disparate definition of the medication/diagnosis or if the diagnosis is through a selfreport rating scale or by a structured interview (42). Depression encompasses both MDD and minor depression; MDD is a distinct clinical syndrome for which treatment is indicated whereas minor depression is an impairing, yet less severe, set of depressive symptoms where the definition and management are less defined (43). Both ICD-10 and DSM-5 are lacking an adequate definition of mild depression (39). 
Table 2. DSM-5 criteria for MDD

\begin{tabular}{|l|l|}
\hline $\begin{array}{l}\text { Five or more out of nine symptoms } \\
\text { including at least one of depressed mood and } \\
\text { loss of interest or pleasure) in the same 2 week } \\
\text { period. }\end{array}$ & Frequency requirements: \\
$\begin{array}{l}\text { Each of these symptoms represents a change from } \\
\text { previous functioning. }\end{array}$ & \\
\hline $\begin{array}{l}\text { Depressed mood (subjective or observed); can be } \\
\text { irritable mood in children and adolescents }\end{array}$ & Most of the day, nearly every day \\
\hline Loss of interest or pleasure & Most of the day, nearly every day \\
\hline Change in weight or appetite & $\begin{array}{l}\text { Appetite: Nearly every day } \\
\text { Weight: 5\% change over 1 month }\end{array}$ \\
\hline Insomnia or hypersomnia & Nearly every day \\
\hline Psychomotor retardation or agitation (observed) & Nearly every day \\
\hline Loss of energy or fatigue & Nearly every day \\
\hline Worthlessness or guilt & Nearly every day \\
\hline Impaired concentration or indecisiveness & Nearly every day \\
\hline Thoughts of death or suicidal ideation or attempt & $\begin{array}{l}\text { Thoughts: recurrent } \\
\text { Attempt: any }\end{array}$ \\
\hline Symptoms cause significant distress or impairment (compulsory). \\
\hline Episode not attributable to a substance or medical condition (compulsory). \\
\hline
\end{tabular}

Providers of antenatal health care must be careful to get both a medical and psychiatric history from the pregnant woman. A history of depressive episodes earlier in life constitutes a risk for a relapse of depression. Pregnant women can also have a pre-existing depression which require special attention during pregnancy.

Sometimes it can be difficult to distinguish between "normal" pregnancy symptoms, which can be common during pregnancy such as "loss of energy or fatigue" or "insomnia and hypersomnia" and depression symptoms (44). The symptoms of major depression during pregnancy, i.e. antenatal depression, do not differ from depression during other times in life.

For this reason, midwives and/or physicians at the antenatal care clinic should consider asking the following questions about the woman's mental health (45):

- During the past month, have you often been bothered by feeling down, depressed or hopeless?

- During the past month, have you often been bothered by having little interest or pleasure in doing things?

- Over the last 2 weeks, how often have you been bothered by feeling nervous, anxious or on edge?

- Over the last 2 weeks, how often have you been bothered by not being able to stop or control worrying? 
The above questions have also been translated into Swedish and are recommended as a support for midwives working in the Swedish antenatal health care system (46).

If the woman responds positively to any of the questions above the Edinburgh Postnatal Depression Scale (EPDS) (47) can be used for a more thorough assessment. EPDS can also be used alone as a screening tool for all pregnant women in an antenatal care setting (48).The EPDS is the most widely used self-report screening tool for depressive symptoms during the perinatal period. It has been validated in many languages as well as in Swedish (49).

Antenatal depression is one of the most prevalent disorders during pregnancy (4) and affects around $12 \%$ of pregnant women globally (50). The prevalence of perinatal depression is probably higher in low- and middle-income countries compared with high-income countries although fewer studies have been conducted in these areas (51).

Suicide, although rare, remains one of the most common causes of death during the year following delivery in high-income countries, such as Sweden (52). Affective and psychotic disorders, including a history of self-harm, were the most common risk factors (53).

The strongest risk factors for antenatal depression is a history of depression; almost half of the women depressed during pregnancy had a past history of MDD and half of the women with depression during pregnancy had never been depressed before. Other risk factors, regardless of a history of depression are fear of childbirth, adolescent or advanced maternal age, low or unspecified socioeconomic status, single marital status, smoking, prior pregnancy terminations, anaemia, and gestational diabetes (54). Furthermore, a history of abuse or domestic violence, unplanned or unwanted pregnancy, present or past pregnancy complications such as pregnancy nausea, and symphysiolysis are also risk factors for antenatal depression $(42,55)$.

\section{Antidepressant medication}

Almost all antidepressant drugs are based on the monoamine hypothesis, which assume that the underlying pathophysiologic basis of depression is due to depleted concentrations of the monoamine neurotransmitters in the central nervous system (i.e. serotonin, norepinephrine and dopamine) (56, 57). These neurotransmitters are linked to mood and emotions. Most of the 
antidepressant drugs share the same mechanism, which involves the modulation of monoaminergic neurotransmission at a synaptic level to increase the levels of neurotransmitters.

The first antidepressant medications were introduced in the late 1950s; Iproniazid was developed as for the treatment of tuberculosis. Side effects of the medication included euphoria, increased appetite, and improved sleep and it was therefore used off-label to treat patients with depression (58). Ipronazid is a monoamine oxidase inhibitor (MAOI) which inhibit the enzyme that breaks down monoamine neurotransmitters.

The next class of antidepressants to be introduced in 1959 was tricyclic antidepressants (TCA) named after the three benzene ring molecular core, in part, because the mechanism of action was unknown at the time of discovery. It was eventually shown that TCAs, have serotonin and noradrenaline reuptake inhibiting effects in addition to different degrees of affinity to $\alpha_{1-}$ adrenergic receptors, histamine ${ }_{1}$-receptors, and muscarinic-cholinergic receptors in the central nervous system (59). Both MAOIs and TCAs have side effects and further drug development were aimed at safer drugs with less side effects.

In 1988 the first widely used serotonin reuptake inhibitors (SSRI) drug was presented. SSRIs selectively inhibit the reuptake of serotonin at serotonin transporters, and as a result this increases the concentration of serotonin (60). Different kinds of SSRI with different affinity for the serotonin receptor are sertraline, citalopram, paroxetine, fluoxetine and escitalopram. Other indications for SSRI treatment than depression are obsessive-compulsive disorder, panic disorder, and generalized anxiety disorder $(61,62)$.

The next more commonly used antidepressant class to be introduced were SNRIs in 1993. SNRIs inhibit the reuptake of serotonin and norepinephrine. SNRIs registered in Sweden are venlafaxine and duloxetine (63).

\section{Antidepressant medication during pregnancy}

Pharmacological treatment for depression is common and an increasing number of pregnant women are treated with antidepressant drugs $(61,64-$ 67). Non-pharmacological interventions, such as cognitive behavioural therapy and interpersonal therapy are recommended for mild-to-moderate depression during pregnancy (68), while antidepressants are indicated for more severe forms or when other treatment options are inaccessible or ineffective (69). 
SSRIs are the most common drugs for treating depression during pregnancy (70, 71), followed by SNRIs (prevalence ranging from $0.55 \%$ to $0.73 \%$ ) and TCAs (prevalence ranging from $0.38 \%$ to $0.62 \%$ ) (72). Between 2 and $7 \%$ of pregnant women in the Nordic countries (Finland excluded) use antidepressant medication $(73,74)$. In other parts of Europe 1.2-4.5\% of pregnant women use SSRIs $(64,66,75,76)$. The prevalence of women treated with an SSRI during pregnancy in the US is similar to that in Europe, i.e. $4.3-6.0 \%(67,77)$. Sertraline was the most commonly used SSRI during pregnancy, with a prevalence rate of $1.1 \%$ followed by citalopram $(0.77 \%)$, fluoxetine $(0.76 \%)$, paroxetine $(0.56 \%)$, escitalopram $(0.47 \%)$ and fluvoxamine $(0.01 \%)$ ( 72$)$.

Many women discontinue their antidepressant drug treatment during pregnancy (78-80) most commonly due to apprehension of potential negative side effects to the foetus, health professional advice and/or symptomatology that was under control (81). The women who discontinue their medication have a higher risk of relapsing during pregnancy compared with women who maintained their antidepressant medication $(4,78,82)$. Discontinuation of antidepressant medication during pregnancy leads to treatment resumption in $12-57 \%$ of the cases before childbirth $(75,83-85)$. Factors associated with treatment resumption for pregnant women in Sweden are: a greater burden of pre-pregnancy psychiatric illnesses, multipara, higher educational level and have been born in the Nordic countries or the EU. Difference in severity of the psychiatric illness prior to pregnancy could explain the divergent results in the studies above (85). Among those continuing with antidepressants, however studies have shown that the overall rate of adherence to the medication varies between 60 and $86 \%(86,87)$.

\section{Depression and risks for adverse maternal and neonatal outcomes}

Antenatal depression is associated with both adverse maternal and neonatal outcomes. Women with depression during pregnancy have a higher likelihood of tobacco smoking, alcohol consumption, drug intake, poor antenatal care and poor nutrition which in themselves are also risk factors for complications during pregnancy and delivery (88). Depressed pregnant women both with antidepressant medication and without medication have a higher risk for operative delivery (i.e. use of obstetrics forceps, vacuum extraction (VE) or caesarean section (CS) compared with pregnant women who have no history of depression $(83,89,90)$. 
Concerning foetal malformations no overall increased risk associated with the use of SSRIs has been found (88). However, a slightly increased risk of cardiovascular malformations in infants exposed to paroxetine in the first trimester cannot be ruled out $(91,92,93)$.

Poor Neonatal Adaptation Syndrome (PNAS) includes a range of physical and neurobehavioural symptoms similar to adult withdrawal symptoms. Irritability, jitteriness, respiratory distress, seizures and low blood sugar are seen in up to $30 \%$ of infants exposed to antidepressants. Symptoms are most commonly associated with withdrawal from short half-life antidepressants, such as venlafaxine or paroxetine but have also been associated with all other antidepressants. The risk of PNAS does not appear to be dose-related and the condition is transient but may require a stay in the neonatal intensive care unit (NICU) $(94,95)$. Most symptoms develop within 48 hours after birth and last for 2-6 days (94). A Swedish study found that the admission rate to NICU overall after treatment with SSRI during late pregnancy was $16.5 \%$ mostly due to PNAS, compared with $10.8 \%$ after treatment during early pregnancy only (96).

Studies have shown that the average gestational length is shorter in women taking antidepressants compared with population controls. Also women with untreated depression have been shown to have a shorter gestational length, but the actual difference in days are however low (absolute differences were less than a week) $(97,98)$. When it comes to preterm birth (birth before 37 completed weeks of gestation) the results from different studies are more divergent since this outcome is more rare (97). In a meta-analysis by Eke et al (99), there was a small increased risk of preterm birth in pregnant women under SSRI treatment compared both to control women with depression but without SSRI or women without depression. However, this association was not constant over all studies, some of them indicating even a lower rate of preterm birth in SSRI-treated mothers suffering of psychiatric disorders compared to untreated controls. Regarding the risk of lower birth weight, a review article by Mitchell et al (97) found that the risk associated with antidepressants and the risk associated with untreated depression are similar, the majority of studies included found no significant difference. Another review article found a small increase for the risk of lower birth weight for SSRI treated mothers compared to population controls but the absolute risk in grams were -200 to $-70 \mathrm{~g}(88)$. 
Different mechanisms have been suggested to explain these associations. One hypothesis proposes that untreated depression leads to an impaired regulation of the hypothalamic-pituitary-adrenocortical axis with an increased release of stress hormones such as cortisol and catecholamines (norepinephrine, epinephrine and dopamine). Women with antenatal depression have been shown to have significantly higher stress-related biomarkers, e.g. cortisol and interleukin-6, during the third trimester of pregnancy than controls. These women's children had an increased cortisol response to stress at one year of age (100). Studies have shown that maternal cortisol stimulates the production of cortisol releasing hormone in the placenta. This in turn affects the hypothalamic-pituitary-adrenocortical axis in the foetus, with higher levels of foetal cortisol (101). Antenatal maternal cortisol levels and antenatal depression have also been shown to be associated with alterations in the foetal amygdala, a structure associated with emotion regulation, and suggest a prenatal mother-child transmission of vulnerability (102).

However, it is still unclear whether the higher risk for adverse maternal and neonatal outcomes are due to the antidepressant medication, the psychiatric illness in itself or a combination of these and/or other factors. One cannot only compare the risks of exposure of the mother or the foetus to the medication with the risk of non-exposure, but also to the risks of exposure of untreated antenatal depression since there are many other factors, apart from the medication in itself, that can impact the outcomes.

\section{Postpartum depression}

Postpartum depression is one of the most common complications of childbirth and can affect up to $10-15 \%$ of women (98). In clinical practice postpartum depression is often defined as depression that occurs up to 12 months after childbirth (103). The DSM-5, though classifies postpartum depression as a major depressive episode "with peripartum onset if onset of mood symptoms occurs during pregnancy or within four weeks following delivery". Postpartum depression has the same diagnostic criteria as nonperinatal depression (104). Women with untreated depression during pregnancy have an increased risk of postpartum depression $(105,106)$. Postpartum depression can have negative implications for the infant/child and the wider family context such as negative effects on mother-infant 
bonding and the parental relationship (107), and on the emotional or behavioural development of the child (108). There is also a positive association between both maternal and paternal depression, as well as maternal depression and the risk of depression in adolescence and adulthood for the offspring $(109,110)$. From a global perspective depression reduces the response to a child's need, and treatment of depressed mothers leads to improved growth and development of the child. According to the WHO, treatment also reduces the likelihood of diarrhoea and malnutrition among new-borns, since women without depression are more likely to breastfeed (111). 


\section{Specific background to the present studies}

It can be a challenge to counsel pregnant women about medication; many women want to avoid medication as much as possible during pregnancy and while breastfeeding due to concerns and beliefs about adverse effects of medication for the foetus and the child. They may also have been advised by health professionals in specialties other than obstetrics/gynaecology to discontinue medication treatment, due to lack of knowledge about medication during pregnancy. Through my own clinical experience this happens most frequently when the women use antidepressant medications. On the other hand, many women use medication during pregnancy, and the use of antidepressants during pregnancy has become more frequent. This illustrates the need for more studies concerning these issues.

There are few studies concerning women's perception of medication use during pregnancy, and even fewer studies that only include pregnant women and not also women who have recently given birth. To my knowledge there are no studies about pregnant women's perceptions in Sweden. Knowing more about pregnant women's perceptions and concerns about medication use may lead to better counselling during the antenatal care.

Many studies exploring the possible teratogenic effects of drugs are based on information in the Swedish Medical Birth Register (MBR), which retrieves its information from the Swedish standardised antenatal medical records. Regarding medication use in the MBR, one previous study has explored the agreement between use according to the MBR and The Swedish Prescribed Drug Register (PDR). However no prior studies have looked at the agreement between the MBR and the actual drug content in the blood of pregnant women.

Study III originated from the clinical problem of whether the pregnant woman should continue with her antidepressant medication or not; what are the consequences of continuing or discontinuing the treatment? Some previous studies have examined obstetric and neonatal outcomes in relation to whether the pregnant women used antidepressant medication before and/or during pregnancy, but fewer have studied both outcomes simultaneously, and none of these studies was carried out with a Swedish population. 
Knowledge of the PK of antidepressant drugs in pregnant women is still scarce and often inconclusive. Few studies have been performed, and the number of women included is often limited. Further information is therefore of the utmost importance to strengthen and support clinical recommendations and decision-making when prescribing antidepressant drugs to pregnant women. 


\section{AIMS}

\section{General aim}

\section{The overall aim of this thesis is to examine different aspects of drug use during pregnancy with an emphasis on antidepressant medication treatment.}

\section{Specific aims}

- To examine the perceptions of pregnant women regarding medication use in general as well as the use of herbal medicines during pregnancy and breastfeeding and to investigate from which sources pregnant women obtain information about the use of medication during pregnancy and how reliable they have found these sources to be. (Study I)

- To investigate the reliability of reported drug use in early pregnancy, gestational weeks (gw) 10-12, and mid pregnancy gw 25, by simultaneous screening for drug substances in the plasma of pregnant women, to assess drug adherence and consequently the validity of the MBR. (Study II)

- To investigate the impact of depression and antidepressant medication before and during pregnancy on obstetric and neonatal outcomes. (Study III)

- To investigate changes in dose-corrected serum concentration of five commonly prescribed antidepressant drugs throughout pregnancy. (Study IV) 


\section{MATERIAL AND METHODS}

A brief overview of the subjects and methods of the four studies is presented in table 3 .

Table 3. Overview of the studies included in the thesis

\begin{tabular}{|c|c|c|c|c|}
\hline PAPER & I & II & III & IV \\
\hline Study design & $\begin{array}{l}\text { Cross-sectional } \\
\text { questionnaire study }\end{array}$ & Exploratory study & $\begin{array}{l}\text { Population based cohort } \\
\text { study }\end{array}$ & $\begin{array}{l}\text { Prospective and } \\
\text { naturalistic } \\
\text { pharmacokinetic study }\end{array}$ \\
\hline Years & 2015-2016 & 2013 & 2012-2015 & 2011-2014 \\
\hline Data sources & Questionnaires & $\begin{array}{l}\text { Electronic medical } \\
\text { records and biobank }\end{array}$ & MBR, PDR, NPR, TPR & $\begin{array}{l}\text { Blood samples and } \\
\text { electronic medical } \\
\text { records } \\
\text { laboratory reports }\end{array}$ \\
\hline $\begin{array}{l}\text { Study } \\
\text { population }\end{array}$ & $\begin{array}{l}850 \text { pregnant women } \\
\text { in gw } 25-29\end{array}$ & $\begin{array}{l}200 \text { pregnant women } \\
\text { included in the } \\
\text { biobank }\end{array}$ & $\begin{array}{l}262,329 \text { women who } \\
\text { gave birth during the } \\
\text { years } 2012-2015\end{array}$ & $\begin{array}{l}81 \text { pregnant women } \\
\text { with ongoing } \\
\text { antidepressant treatment }\end{array}$ \\
\hline Exposures & Pregnancy & Drug exposure & $\begin{array}{l}\text { Antidepressant } \\
\text { medication }\end{array}$ & $\begin{array}{l}\text { Antidepressant } \\
\text { medication }\end{array}$ \\
\hline $\begin{array}{l}\text { Outcome } \\
\text { measures }\end{array}$ & $\begin{array}{l}\text { Use of medication, } \\
\text { perceptions on use of } \\
\text { medication, and } \\
\text { perceptions about } \\
\text { pregnancy outcomes } \\
\text { in association with } \\
\text { medication use } \\
\text { during pregnancy }\end{array}$ & $\begin{array}{l}\text { Coherence between } \\
\text { reported drug intake } \\
\text { and presence of the } \\
\text { drug in the pregnant } \\
\text { women's blood. }\end{array}$ & $\begin{array}{l}\text { Obstetric and neonatal } \\
\text { outcomes }\end{array}$ & $\begin{array}{l}\text { Antidepressant drug and } \\
\text { metabolite } \\
\text { concentrations measured } \\
\text { throughout pregnancy. } \\
\text { S-albumin, } \\
\text { creatinine and CYP2D6 } \\
\text { and 2C19 genotype. }\end{array}$ \\
\hline Statistics & $\begin{array}{l}\text { Descriptive statistics, } \\
\text { student's t-test, Chi- } \\
\text { square test }\end{array}$ & Descriptive statistics & $\begin{array}{l}\text { Descriptive statistics, } \\
\text { Chi-square test, single } \\
\text { and multiple logistic } \\
\text { regression }\end{array}$ & $\begin{array}{l}\text { Mann-Whitney U test, } \\
\text { Kruskal-Wallis test, } \\
\text { ANOVA, repeated } \\
\text { measurement analysis } \\
\text { using linear mixed } \\
\text { models }\end{array}$ \\
\hline
\end{tabular}




\section{DATA SOURCES}

\section{National registers}

In Study III data from four different registers were used; the MBR, the PDR, the Swedish National Patient Register (NPR) and the Total Population Register (TPR). Every person residing in Sweden is assigned a personal identity number (PIN), allowing linkage of information in different registers. All these registers have been validated (112-116).

- The MBR contains information on practically all pregnancies, including prenatal care, childbirth and neonatal care, in Sweden (12\% missing) since 1973 (112). Since 1994, information on drug treatment use during pregnancy has been forwarded to the MBR from the antenatal medical records.

- The PDR contains information on all prescriptions that were redeemed from 2005, including the date of buying the drug, and the Anatomical, Therapeutic, Chemical (ATC) code of the drug. There is also information on the date of prescribing and dispensing, as well as on the prescriber's profession and practice (113).

- The NPR from 1987 includes diagnoses of all patients who have been discharged from hospital, and from 2001, all out-patient visits in specialised healthcare (114). It does not contain diagnoses received in general practice. The diagnoses are based on the Swedish version of the ICD. More than $99 \%$ of all somatic and psychiatric hospital discharges are registered in the NPR (115).

- The TPR was established in 1968. The register contains information on variables such as births, family relations, country of birth for Swedish residents born abroad, deaths and migrations (116).

\section{Electronic medical records}

For Studies II and IV pregnancy data were collected from the electronic medical record system Obstetrix ${ }^{\circledR}$ (Cerner). Information on pregnant women who attend the maternal antenatal clinics in the Region Jönköping, Region Kalmar and Region Östergötland is recorded in Obstetrix ${ }^{\circledR}$. This EMR system contains detailed, prospectively registered information for each pregnancy from the first visit to the antenatal clinic until the postpartum check-up approximately six to eight weeks after childbirth, including information about the birth. These data include maternal reproductive, 
demographic and health data, prenatal medical diagnoses and the pregnancy outcome for the mother and the infant.

\section{Biobank and maternal blood samples}

For drug analyses in Study II, maternal blood samples from women included in GRABB (Swedish Graviditetsbiobanken, register number 185), a local pregnancy biobank at the department of Obstetrics and Gynaecology in Linköping were used. All pregnant women at the antenatal care centres in Linköping and later also Motala were asked to participate. In this biobank blood samples were drawn from the women on two occasions during pregnancy (gw 10-12 and gw 25) and during delivery as well as from the umbilical cord, for study purposes. GRABB was started on 31/03/2011, and recruitment ended on 31/05/2018. More than 7000 women were included in GRABB, including approximately $55 \%$ of women attending these antenatal care centres.

In Study IV pregnant women in the south east region of Sweden with ongoing antidepressant treatment were recruited in antenatal care centres. At the first visit they were genotyped for CYP2D6 and CYP2C19, and serumantidepressant drug concentrations, as well as albumin and creatinine, were taken. Around gw 15, 20, 25, 35, and at partus, the antidepressant drug concentration sampling procedure was repeated including taking a blood sample from the umbilical cord.

\section{STUDY POPULATIONS AND STUDY DESIGNS}

\section{Study I}

\section{Study population}

In Study I, pregnant women at 18 antenatal care centres in the south east region of Sweden were asked to participate in a questionnaire study at gw 25-29. These weeks were chosen because most of the women at this point in their pregnancies have not given birth and there is no longer a risk of miscarriage. The number of women who declined to participate was recorded. When 850 questionnaires had been were distributed (the 
predetermined number of participants to be included), the study was concluded.

\section{Exposure}

The exposure in Study I was pregnancy: pregnant women $\geq 18$ years old and who understood the Swedish language in both spoken and written form were included. Women with a known foetal malformation were excluded.

\section{Outcomes - the questionnaire}

There is a validated questionnaire for general perceptions about medications, the Beliefs about Medicines Questionnaire (BMQ) (117). Parts of the BMQ has been translated into Swedish (118) but the questionnaire had not been validated in Swedish at the time of the study (119).

A questionnaire concerning pregnant women's perceptions of medications was developed in collaboration with an expert in questionnaire construction. Parts of the BMQ were used (Appendix). To ensure that the questions were correctly understood, 38 pregnant women were asked to answer the preliminary version of the questionnaire in writing. These women were thereafter interviewed and if any question was unclear, they were asked to rephrase the questions using their own words. Afterwards the questionnaire was modified in order to make it easier to understand. After the adjustments, another 19 pregnant women were interviewed in the same way and no further alterations to the questionnaire were made. After the second modification, the validity was considered good.

The questionnaire contained questions about the usage of medications for a number of symptoms and diseases, e.g. hyperemesis, pain, depression, and asthma or allergies. Questions about perceptions regarding medication and herbal medicines use during pregnancy and breastfeeding compared with before pregnancy and concerns about foetal malformations, as well as perceptions about pregnancy outcomes in association with medication use were also included in the questionnaire. In addition, there were questions regarding where the pregnant women had sought advice and information on medication use during pregnancy and on how reliable they had found these sources to be. The questionnaire included in total 55 questions with multiplechoice answers. Since the study was about perceptions of medication and not about knowledge, a deliberate choice was made not to have a "do not know" option for most of the questions. There were also four choices of answers to most of the questions, in order to avoid the respondents choosing the option 
in the middle since this option both includes respondents who purposely choose this answer and respondents with no opinion (120).

Perceptions on use of medication and perceptions about pregnancy outcomes in association with age, education, parity and medication use during pregnancy were thereafter investigated.

\section{Study II \\ Study population}

Plasma samples from the first 200 women consecutively recruited in the year 2013 were extracted from the biobank (GRABB). These samples had been obtained on the same days as the interviews on medication noted in antenatal medical records were conducted by the midwife at the antenatal care centre. The blood samples were collected in one EDTA tube and one serum gel tube. Within one hour of the blood sampling, the blood was centrifuged, aliquoted and stored at minus 70 degrees Celsius. The blood samples were collected at gw 10-12 and then at gw 25. In total 400 blood samples were analysed.

\section{Exposure}

Blood samples were screened for drugs by using ultra-high performance liquid chromatography with time of flight mass spectrometry (UHPLC-TOFMS). This is a technique used to separate, identify, and quantify compounds found in complex samples of biological origin that can be dissolved in a liquid. TOF-MS analyse ions based on their mass-to-charge ratio. Ions are accelerated by an electric field and then enter a vacuum chamber. In this chamber there is no electric field, and the ions move only by the kinetic energy they acquired when they were accelerated. Heavier ions of the same charge move more slowly and therefore reach the detector later than smaller ions with the same charge. Based on the time it takes for ions to move from one end of the chamber to the detector at a known distance, this can be used to calculate their mass-to-charge ratios (121). 


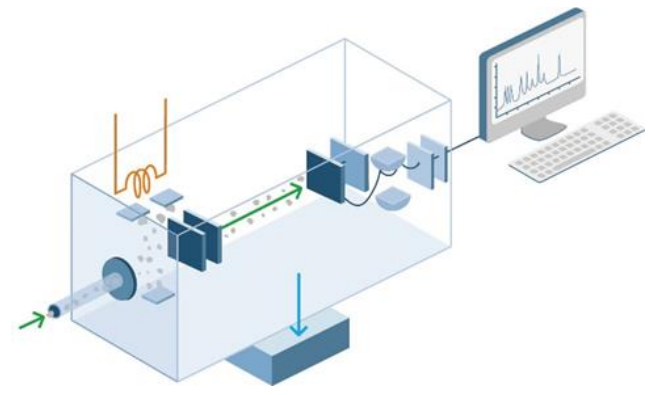

Figure 1, principles of mass spectrometers which consist of four parts;

1. handling system to introduce the unknown sample into the equipment

2. ion source, in which a beam of particles characteristic of the sample is produced

3. analyser that separates the particles according to mass

4. detector in which the separated ion components are collected and characterized.

Retrieved October 8th 2020 from http://hiq.linde-gas.com/en/analytical_methods/gas_chromatography/mass_spectrometry.html

A screening was performed by matching the results with an in-house database comprising more than 500 drugs and metabolites confirmed by the access of reference substance. In this study, all findings from the complete database that fulfilled the criteria for identification by TOF-MS were reported. Some drugs, such as insulin or levothyroxine, were not detectable in this screening, for analytical technical reasons.

Drugs registered in the antenatal medical records at gw 10-12 and gw 25 were compared with the findings from the plasma drug analyses. All relevant background data were also extracted from the antenatal medical records.

\section{Outcomes}

The coherence between reported drug use at early pregnancy, gw 10-12, and mid pregnancy, gw 25 and the drug screening for drug substances in the plasma of pregnant women, to assess drug intake and consequently the validity of the MBR.

\section{Study III}

\section{Study population}

Study III included women born in Sweden between 1973 and 1993, who had given birth during the years 2012-2015 ( $\mathrm{n}=262,329)$. Only the first child born to each individual during the study period was included. Information on the study participants and their children was retrieved from Swedish population registers.

\section{Exposures}

The women included in Study III had redeemed a prescription for an antidepressant and had a major depression before, and/or during pregnancy. Women with a depression diagnosis (MDD) according to the Swedish version of ICD-10 from the WHO, were identified as codes 
F32-33. The ATC code for medication used in this study was N06, psychoanaleptics, in which antidepressant drugs such as SSRIs are the major drug group included.

Having redeemed a prescription for an N06 drug and having been diagnosed with MDD within specialised health care 12 months prior to becoming pregnant defined the group of women "before pregnancy". Some of these women had both redeemed an N06 drug and been diagnosed with MDD both before and during pregnancy, and constituted the group "before and during pregnancy". All women who had neither been diagnosed with depression nor been prescribed an N06 drug were used as a comparison group (population controls). Women who only had a prescription for an SSRI or only had a MDD diagnosis were excluded (Figure 2).

Figure 2. Definition of group and group sizes

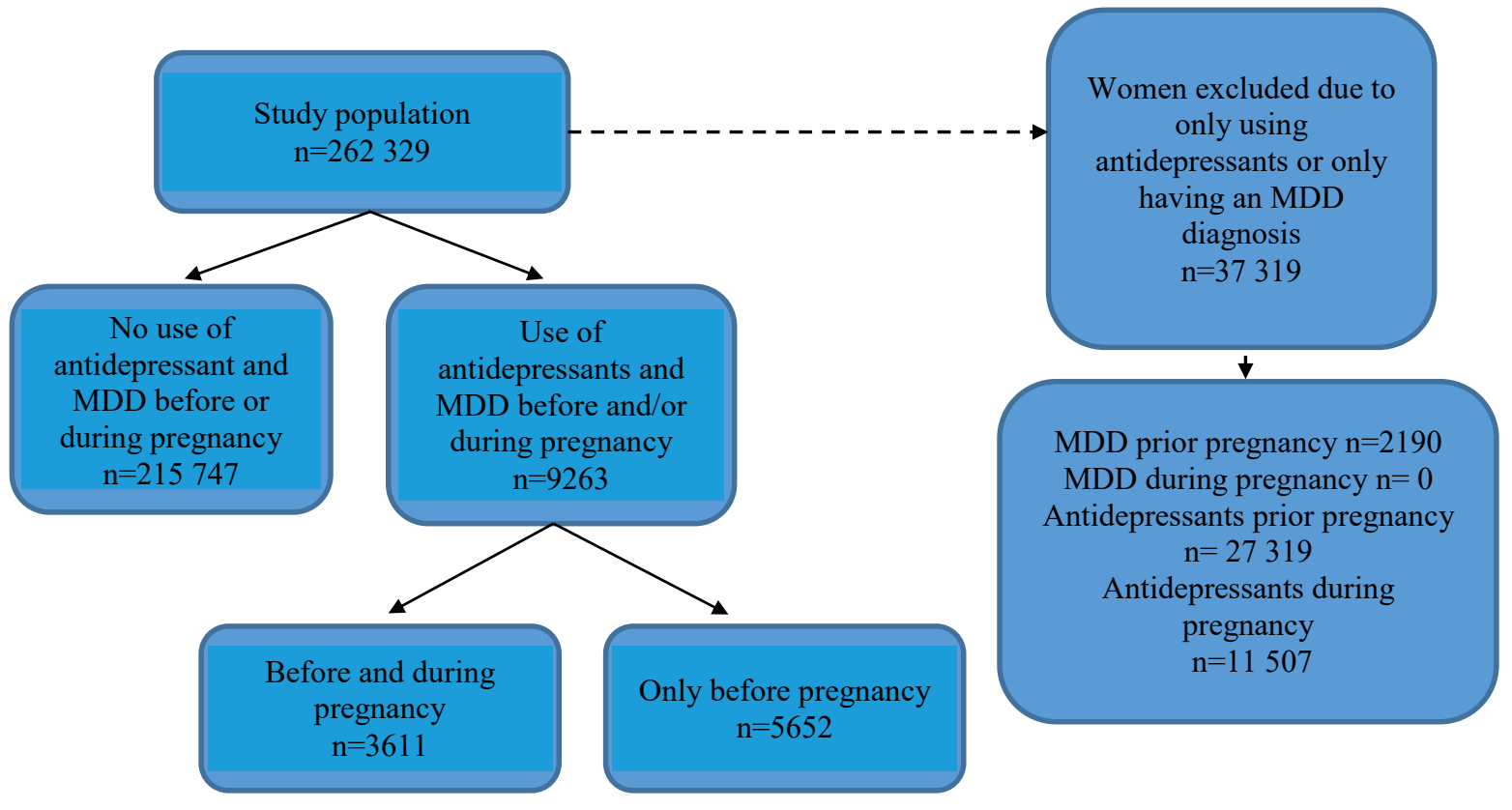

\section{Outcomes}

Obstetric outcomes included: hyperemesis, preeclampsia, induced labour, use of epidural analgesia, mode of childbirth (emergency CS, elective CS, VE, or vaginal childbirth).

Neonatal outcomes included: gestational age (preterm birth (PTB)/term birth), birth weight (low birth weight (LBW)/normal birth weight), small for 
gestational age (SGA), APGAR at five minutes, and admission to NICU. The definition of PTB was birth before 37 completed weeks of gestation (gw $<37$ weeks +0 days). SGA is specified as a birth weight $<2$ standard deviations (SD) of the mean birth weight for the gestational length (122). "Low birth weight" was defined as $<2500 \mathrm{~g}$.

\section{Study IV}

\section{Study population}

Pregnant women in the Southeast region of Sweden with ongoing antidepressant treatment were recruited in the antenatal care clinic during the years 2011-2013.

\section{Exposures}

Pregnant women taking one of the five most common antidepressant medication, regardless of indication.

\section{Outcomes}

Serum- antidepressant drug and metabolite concentrations, albumin and creatinine were measured throughout pregnancy and at the delivery. Participants were genotyped for relevant enzymes involved in antidepressant drug metabolism, CYP2D6 and CYP2C19. The genotypes CYP2D6 and CYP2C19 were classified according to the number of functional alleles into PM, IM, EM and UM (33).

\section{STATISTICS}

Descriptive statistics: categorical data are presented as total number (n) and percentage (\%) (Study I-IV) while continuous data are presented as mean and SD (Study III). A p-value $<0.05$ was considered statistically significant.

\section{Study I}

A student's t-test was used to test differences between quantitative variables. When we looked at perceptions of medication and herbal medicines in relation to education, parity, age and medication use, Pearson's chi-square test was used for testing differences in proportions between categories. 


\section{Study II}

In this descriptive study of drug use in pregnant women, categorical data were presented due to a small sample size.

\section{Study III}

Women in "before and during pregnancy", "before pregnancy" and population controls were compared to each other. The group differences with respect to socio-demographic factors, and obstetric and neonatal outcomes were analysed using Pearson's chi-square statistic.

Additional analyses included single and multiple logistic regression models for several variables. Adjustments were made for the following variables: socio-demographic factors i.e. maternal age at childbirth, parity, body mass index, multiple gestation, use of tobacco during pregnancy, and conception using assisted reproductive techniques. Maternal medical background included: maternal diabetes and hypertension, or other chronic diseases (systemic lupus erythematosus, asthma, inflammatory bowel disease, renal failure and epilepsy). We used these variables because they could possibly independently impact the risk of adverse outcomes.

\section{Study IV}

In cases where the serum concentration was above limit of quantitation but below limit of detection, a random concentration between limit of quantitation and limit of detection was assigned. The estimated glomerular filtration rate, eGFR $\left(\mathrm{mL} / \mathrm{min} / 1.73 \mathrm{~m}^{2}\right)$ was calculated based on creatinine according to Nyman et al (123).

The Mann-Whitney U test was used for comparisons between two groups and the Kruskal-Wallis test for $>2$ groups. Due to the small number of included women, statistics could not be calculated for three of the five included antidepressant drugs. For two of these drugs, an ANOVA comparing gestational weeks did not seem to indicate any changes.

When analysing the concentrations changes over time, repeated measurement analyses using linear mixed models were performed, gestational age at each measurement was included as a covariate and sampling ID (i.e. 1st, 2nd, 3rd, 4th, 5th or 6th sample) as a fixed factor.

All analyses were performed using IBM SPSS, versions 22, 24 and 26 (IBM Inc., Armonk, NY, USA). In Study IV GraphPad PRISM, version 8.3.0 (GraphPad Software, Inc, San Diego, CA) was also used. 


\section{ETHICAL APPROVAL AND CONSIDERATIONS}

The studies in this thesis were approved by the Regional Ethical Review Board in Linköping (Study I; Dnr 2015/274-31, Study II; Dnr 2011/490-31, Study III; Dnr 2017/513-31 Study IV; Dnr 2010/335-31).

In Study I, oral and written information about the study was given to the pregnant women by their midwife and they were asked if they wanted to participate. After oral consent was obtained, the pregnant women were asked to complete a questionnaire during the visit and then hand it back in a sealed envelope before leaving the antenatal care clinic. The questionnaires were answered anonymously except for the study population $(n=200)$ in one of the antenatal care centres where the participants were not anonymous, in order to allow a potential follow-up study to be conducted. The questionnaire included questions about medication and worries about teratogenic effects which could cause the pregnant women concerns. None of the 39 pregnant women who were first interviewed and specifically asked about these questions reacted negatively. The women could, however refrain from answering any of the questions in the questionnaire. It was possible for them to withdraw from the study at any time until the questionnaire was returned.

Blood samples from GRABB were analysed in Study II. The women included in the biobank had all given written informed consent. Every woman included in the biobank has, according to the General Data Protection Regulation (GDPR), the opportunity to obtain information about the personal data handled by the biobank. Every woman also has the possibility to contact the administrators of the biobank and withdraw all her blood samples and medical information from the biobank whenever she wants to.

In Study III data were drawn from Swedish national registers and therefore no patient consent was needed. The data were provided by Statistics Sweden and the Swedish National Board of Health and Welfare. An ethical approval is not enough to give access to the registers: the agencies also review each application for a planned study and decide whether the requested data will be released to the research group. Data sets are coded and provided without PINs and it is therefore not possible to identify single individuals. In this manner personal integrity is not jeopardised. For some research questions, 
randomised or other clinical studies are unethical and/or difficult to pursue. Large data sets such as population-based registers give an opportunity to explore these questions and generate new knowledge and hypotheses.

The women in Study IV were included after written and oral information had been provided to them, and they thereafter signed an informed consent form. At every visit the women were subjected to one extra blood sampling outside of clinical routine for measurements of parent and metabolite serum concentrations. In addition to their regular antenatal visits, two more visits were scheduled in order to take blood samples. The blood sampling could cause transient discomfort but since this is the only way to analyse the drug concentrations the potential benefits of the study were considered to outweigh any negative effects. The women included in the study could at any time withdraw from it. 


\section{RESULTS}

\section{Findings of Study I}

The main finding of Study I, a questionnaire study with 850 pregnant women included, was that the majority of the women perceived medication use during early pregnancy $(61.4 \%(\mathrm{n}=501 / 816))$, late pregnancy $(55.6 \%$ $(\mathrm{n}=455 / 819))$ and breastfeeding $(57.78 \%(\mathrm{n}=474 / 821))$ as probably harmful or harmful. These findings were more common in non-users (medication use rarely or never) compared to frequent users (medication use daily to several times a week) (p-value <0.001, <0.001 and 0.007).

When it comes to herbal medicine (herbal medicine was defined as products for self-care with animal or plant origins and sold over the counter), about $37.8 \%(n=309 / 817), 37.1 \%(n=303 / 816)$ and 33.4\% $(n=273 / 816)$ perceived herbal medicine use during early and later pregnancy and breastfeeding respectively as probably harmful or harmful. Herbal medicines were in general perceived as less harmful compared with medication during early pregnancy $(52.3 \%$ vs $15.9 \%$, p $<0.001)$, late pregnancy $(55.3 \%$ vs $26.0 \%$, $\mathrm{p}<0.001)$ and during breastfeeding $(52.4 \%$ vs $20.8 \%$, $\mathrm{p}<0.001)$.

The perceptions of medication and herbal medicine use in relation to age, parity and educational level were analysed. For educational level and parity we found no differences in perceptions concerning medication use in general during pregnancy and breastfeeding. However when it came to age, we found that younger women $(<30$ years) perceived medication use during early $(\mathrm{p}=0.04)$ and late $(\mathrm{p}=0.026)$ pregnancy as less harmful than older women ( $\geq 30$ years) did. Younger women $(<30$ years) also perceived herbal medicines use during early $(\mathrm{p}=0.004)$ and late $(\mathrm{p}<0.001)$ pregnancy as well as during breastfeeding $(\mathrm{p}=0.004)$ as less harmful compared with older women ( $\geq 30$ years). 
Figure 3. Perceptions about medication and herbal medicines in relation to age

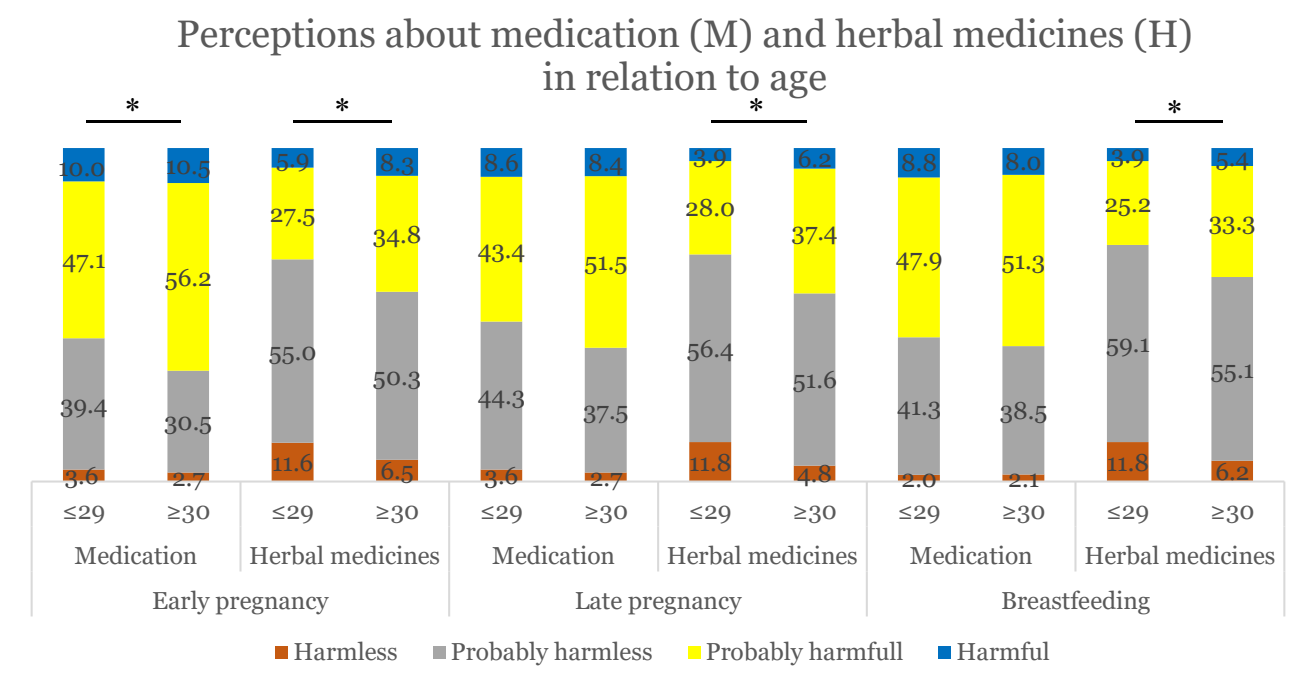

$*=p<0.05$

One third of the women had changed their perceptions concerning medication use since they became pregnant, and a majority agreed (totally or partly) that pregnant women should avoid all kinds of medication. They were also less inclined to use medication during pregnancy compared with when they were not pregnant.

Almost $40 \%(n=21 / 54)$ of the women who had been prescribed an antidepressant medication, reported they had not taken it even though they had need of it. These women also perceived antidepressant use during pregnancy as more harmful compared with those women who used antidepressant medication $(85.7 \%$ vs $21.2 \%, \mathrm{p}<0.001)$.

In addition information sources on medication and the pregnant women's confidence in them were analysed. The majority of the pregnant women had great confidence in advice from physicians working in an antenatal care centre or in a delivery ward $(83.8 \%(\mathrm{n}=666 / 795)$ or in advice from midwives $77.0 \%(\mathrm{n}=620 / 805)$. Only $2.9 \%(\mathrm{n}=22 / 759)$ had great confidence in advice from friends and relatives concerning medication-related questions during pregnancy. 


\section{Findings of Study II}

In Study II a good coherence was found between reported drug intake and the drugs identified in plasma

On the first sampling occasion the drugs found by screening had been reported and noted by the midwife in $86.0 \%$ of the women, and on the second sampling $85.5 \%$. Drugs found in plasma but not reported were associated with OTC drugs for occasional use.

The most common drugs in plasma taken in early and mid-pregnancy were meclizine and paracetamol.

Two types of continuously used drugs: SSRIs and propranolol, were found in the analysis. All women using these medication reported the use of them, and the drug screening revealed a $100 \%$ coherence (Table 4 ).

Table 4. Drugs used in pregnancy according to medical records $(n=200)$; drugs found by plasma drug screening $(\mathrm{n}=200)$; and deviations from reported drug intake

\begin{tabular}{|c|l|c|c|c|}
\hline $\begin{array}{c}\text { Gestational } \\
\text { weeks }\end{array}$ & $\begin{array}{c}\text { Medical } \\
\text { records (n) }\end{array}$ & $\begin{array}{c}\text { Blood } \\
\text { samples (n) }\end{array}$ & Deviation \\
\hline $10-12$ & Antiemetic* & 18 & 29 & +11 \\
& SSRI** & 10 & 10 & 0 \\
& Omeprazole & 3 & 1 & -2 \\
& Paracetamol & 21 & 13 & -8 \\
& Diazepam & 1 & 1 & 0 \\
& Cetirizine & 2 & 1 & -1 \\
& Sumatriptan & 1 & 0 & -1 \\
& Loperamide & 1 & 0 & -1 \\
& Ethylmorphine + & 1 & 0 & -1 \\
& Cocillana & & & \\
\hline \multirow{2}{*}{25} & Antiemetic* & 12 & 17 & +5 \\
& SSRI** & 4 & 11 & 0 \\
& Omeprazole & 4 & 6 & +2 \\
& Paracetamol & 1 & 20 & +16 \\
& Phenylpropanolamine & 1 & 1 & +1 \\
& Propranolol & 0 & 1 & -1 \\
& Loperamide & 1 & 0 & -1 \\
& Sumatriptan & & & \\
\hline
\end{tabular}

One woman can use more than one drug.

*promethazine $+/$ - ephedrine and caffeine, meclizine, metoclopramide, ondansetron. **citalopram, escitalopram and sertraline 


\section{Findings of Study III}

In Study III, a nationwide cohort study including 262,329 pregnancies, the main findings were that women with MDD and antidepressant medication prior to becoming pregnant were at increased risk for adverse obstetric and neonatal outcomes compared to women without depression and use of antidepressant medication.

In this study population, 3.5\% (9263/262 329) of the women had an MDD diagnosis and had used antidepressant medication up to one year before they became pregnant. Of the women who were on antidepressant medication and who had been diagnosed with MDD prior to pregnancy, 61.0\% (5652/9263) discontinued ("before pregnancy group") and 39.0\% (3611/9263) continued ("before and during pregnancy") their treatment during pregnancy.

In comparison to population controls, the "before pregnancy" and the "before and during pregnancy" groups had increased likelihoods of operative childbirth $(\mathrm{aOR}=1.19,95 \%$ CI 1.12-1.27, aOR=1.38, 95\% CI 1.28-1.48 respectively), and with an increased likelihood for the child being admitted to NICU $(\mathrm{aOR}=1.51,95 \%$ CI 1.17-1.95, aOR=1.55, 95\% CI 1.14-2.11 respectively). Children born to mothers in the "before and during pregnancy" group had an increased likelihood of preterm birth (aOR=1.72, 95\% CI 1.521.95 respectively), while children to mothers in the "before pregnancy" group had an increased likelihood of low birthweight $(\mathrm{aOR}=1.15,95 \% \mathrm{CI}$ 1.00-1.33) compared with population controls. Women in the "before and during pregnancy" group had an increased likelihood for hyperemesis during pregnancy $(\mathrm{OR}=1.93$, 95\% CI 1.60-2.32), having an operative birth $(\mathrm{OR}=1.17,95 \% \mathrm{CI} 1.06-1.29)$ or a preterm birth $(\mathrm{OR}=1.53,95 \% \mathrm{CI} 1.28$ 1.81) compared to the "before pregnancy" group.

Of the children admitted to NICU; 54\% of the children from the population controls, $66 \%$ of children to mothers in the "before pregnancy" group and $73 \%$ of children to mothers in the "before and during pregnancy group" were diagnosed with "Respiratory and cardiovascular disorders specific to the neonatal period" (ICD-10 codes P20-P29).

Although statistically significant differences were found with respect to PTB and LBW, the actual differences in pregnancy length and birthweight were small. Women in the "before pregnancy" and "before and during pregnancy" groups gave birth one to four days earlier and to children who weighed 20100 grams less compared with population controls. 
Continuation of antidepressant medication during pregnancy somewhat increased the risk for adverse obstetric and neonatal outcomes.

\section{Findings of Study IV}

In Study IV, the most commonly used antidepressant drugs were sertraline and citalopram. Eighty-one women were included; 78 attended the first visit to the antenatal care centre; 69 were followed to partus. Of these women, 42 had continued their antidepressant treatment throughout the pregnancy, and serum samples were obtained for 41 mother-child pairs. For drug use per visit, see table 5 .

Table 5. Drug use per visit

\begin{tabular}{|l|l|l|l|l|l|l|l|}
\hline & Gestational week & Women (n) & \multicolumn{4}{l|}{ Antidepressant drug (n) } \\
\hline & $\begin{array}{l}\text { median }\left(25^{\text {th }}, 7^{\text {th }}\right. \\
\text { percentile) }\end{array}$ & & CIT & ECIT & SERT & VEN & MIRT \\
\hline Visit 1 & $11(10,13)$ & 78 & 19 & 5 & 47 & 6 & 1 \\
\hline Visit 2 & $15(14,21)$ & 71 & 19 & 5 & 41 & 5 & 1 \\
\hline Visit 3 & $22(21,25)$ & 64 & 18 & 5 & 37 & 3 & 1 \\
\hline Visit 4 & $25(25,35)$ & 55 & 14 & 5 & 32 & 3 & 1 \\
\hline Visit 5 & $35(35,36)$ & 38 & 11 & 4 & 21 & 2 & \\
\hline Partus (mother) & $39(39,40)$ & 42 & 11 & 4 & 23 & 3 & 1 \\
\hline Partus (child) & & 43 (one twin & 11 & 4 & $22^{*}$ & 3 & 1 \\
\hline
\end{tabular}

One child sample lost at birth. *=only sample assessed from one of the twins.

CIT=citalopram, ECIT=escitalopram, SERT=sertraline, VEN=venlafaxine, $\mathrm{MIRT}=$ mirtazapine

In a linear mixed models analysis the dose adjusted concentrations of sertraline and citalopram and their metabolites did not change significantly throughout pregnancy (Figure 4 and 5). Due to the small number of included women, statistics could not be calculated for escitalopram, mirtazapine and venlafaxine but the observed concentrations did not appear to change for these drugs; for venlafaxine see figure 6 . 
Figure 4. Dose adjusted concentrations of sertraline (SERT) throughout pregnancy

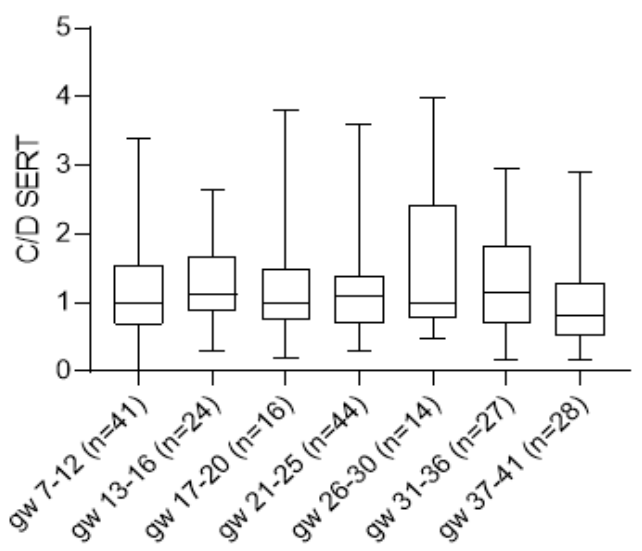

Figure 5. Dose adjusted concentrations of citalopram (CIT) throughout pregnancy

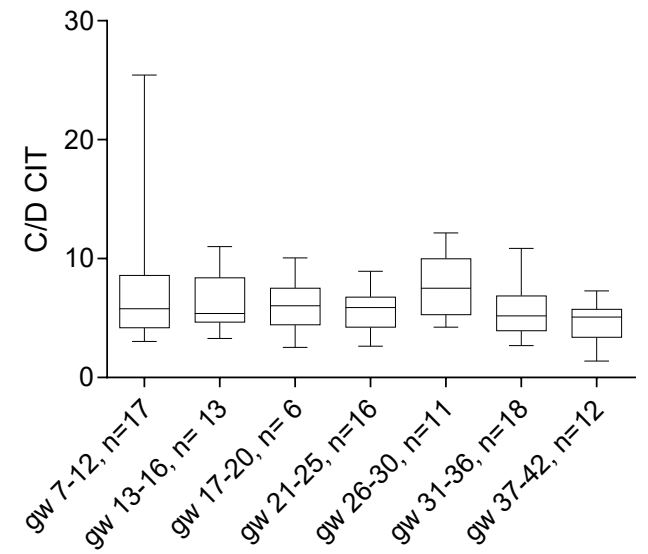

One pregnant woman was a CYP2D6 poor metaboliser and had a noticeably higher concentration of venlafaxine and its metabolites $\mathrm{N}$ desmethylvenlafaxine and didesmetylvenlafaxine in maternal blood samples throughout pregnancy as well as in umbilical cord blood. 
Figure 6. Dose adjusted concentrations of venlafaxine (VEN) throughout pregnancy.

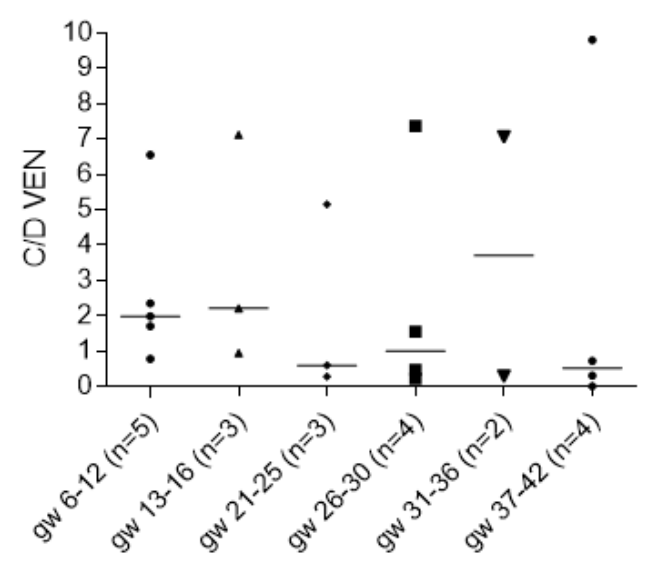

The deviating values are all from the same CYP2D6 poor metabolizing woman.

The median umbilical cord blood concentrations in relation to the mother concentrations; the $\mathrm{U} / \mathrm{M}$ ratio was 0.3 for sertraline $(\mathrm{n}=22) ; 0.7$ for citalopram $(\mathrm{n}=11) ; 0.7$ for escitalopram $(\mathrm{n}=4)$; and 0.8 for venlafaxine $(\mathrm{n}=3)$. The linear mixed models analysis of laboratory data changes over time; visit 1-5, showed significant changes for s-albumin, s-creatinine and eGFR. For all analysis $\mathrm{n}=71$ women; $\mathrm{p}<0.0001$. S-albumin decreased during pregnancy. The mean values at visit 5, $28 \mathrm{~g} / \mathrm{L}$ (95\% CI 27-28), were approximately $74 \%$ lower than the values at 1 st visit, $38 \mathrm{~g} / \mathrm{L}(95 \%$ CI $37-$ 39). S-creatinine increased around $8 \%$, from 1 st visit, $50 \mu \mathrm{mol} / \mathrm{L}(95 \% \mathrm{CI}$ $48-51$ ), to 5 th visit, $54 \mu \mathrm{mol} / \mathrm{L}$ (95\% CI 50-58). eGFR displayed an inverse pattern with a $4.5 \%$ decrease from 1 st visit, $112 \mathrm{ml} / \mathrm{min} / 1.73 \mathrm{~m} 2(95 \% \mathrm{CI}$ 110-114), to visit 5, 107 (95\% CI 102-112). 


\section{DISCUSSION}

\section{METHODOLOGICAL DISCUSSION}

In this thesis, four different study designs were used, each with methodological issues to be considered.

\section{Study I}

Study I was based on a questionnaire. Since there is no validated questionnaire about pregnant women's beliefs about medication we constructed a questionnaire. Validity explains how well the collected data covers the actual area of investigation. Basically, does the questionnaire measure what is intended to be measured? There are different kinds of validity. Face validity evaluate whether the instrument appears appropriate and contains relevant questions. A test has face validity if its content appear relevant to the person taking the test. It evaluates the appearance of the questionnaire in terms of feasibility, readability, consistency of formatting, and the clarity of the language (124). By interviewing pregnant women twice about the questionnaire and making adjustments according to the interviews, we tested the face validity.

In a questionnaire one obtains the information one asks for, which is a limitation. Even though several persons read through the questionnaire numerous times, we failed to include, for example a question about the respondent's own use of herbal medicine, although this was not the main question in the study.

In a survey study there are different kinds of error that can be made:

Respondent error, where the respondent of the questionnaire provides incorrect information. This may be due to misunderstanding of the question, or because the respondent does not want to answer truthfully. By validating the questionnaire in two steps we tried to minimise the possibility of misunderstanding of the questions. By having most of the women reply to the questionnaire anonymously we hoped to obtain more accurate answers and to further minimise respondent error.

Recall bias is when the respondent does not remember the requested information correctly and therefore answers the question falsely. For obstetric and neonatal outcomes, recall bias may be a problem when exposure data are collected after the outcome of the birth is known. For 
example, if a woman gives birth to a child with a foetal malformation, there might be a higher chance that she will remember which medication she took during pregnancy compared with a woman who gives birth to a healthy child (125). Women in this study were included in gw 25-29, and not after they gave birth, in order to reduce the recall bias. Women with a known foetal malformation were also excluded, to further reduce the recall bias.

In many study designs there is the risk of selection bias. Selection bias is systematic error due to differences in characteristics between those who are selected for a study and those who are not (126). The selection of patients for a study can influence the generalisability of the results to other populations. Selection bias can also be an issue if there are differences between those who consent and do not consent to participate in a study, i.e. the response rate. Response rate is most often defined as the proportion of individuals (e.g. pregnant women) selected into a sample who are eligible and participate in the survey. While there are more opportunities for bias when response rates are low rather than high (127), there is not necessarily any relationship between response rates and response bias (128). Response rate could give some information about how representative the survey is; a higher response rate could produce findings that are more representative of the population (129). There is no proven minimally acceptable response rate. A response rate of 50-60\% has been used as the threshold of acceptability $(130,131)$. In our study the response rate was $92.7 \%$ and the average percentage of missing answers in the questionnaire was low (4.0\%) which minimise the risk of response bias.

By distributing the questionnaire in the south east region of Sweden we wanted to increase the generalisability by including both urban and more rural settings. However, we only included women who understood spoken and written Swedish therefore we do not know whether the results are generalisable to a non-Swedish-speaking pregnant population.

\section{Study II}

The study was initially planned to be a pilot study to ascertain that the method worked, and we then intended to perform a larger study with a larger sample size.

A limitation to the study was that not all drugs could be found with the chosen method. The analysis method was performed at the Department of 
Forensic Genetics and Forensic Toxicology in Linköping, where samples in criminal cases are usually analysed and where there is therefore a different focus in their analyses. In this study the drugs reported in the medical records but not found in screening were levothyroxine, inhalation drugs, mesalazine, antibiotics, lactulose, tinzaparin, acetylsalicylic acid, estradiol, progesterone, alginic acid, sterculia gum, ibuprofen, clemastine and aciclovir. A drug is only detectable during a limited time period after intake depending on the half-life of the drug. The blood samples were taken on the same day as the interview in order to minimise this risk as much as possible. There is also a risk that we did not find other drugs which the pregnant women had not reported use of. Nevertheless, other studies have shown a high agreement between self-reported drug data in the MBR and PDR for chronic conditions but low agreement for occasional use $(132,133)$. In Study II only women who agreed to participate in GRABB were included, which could lead to selection bias, since these women may not represent the total population.

\section{Study III}

Study III was a population based cohort study. A cohort is a group of individuals from a defined population followed over time (134). When studying more uncommon outcomes, i.e. foetal malformations, PTB or LBW register studies enables a large cohort which is needed when studying adverse outcomes associated with medication use during pregnancy (135).

However large cohort studies may lead to results that are statistically significant, but the differences may not be clinically relevant.

Since the data are collected routinely and prospectively, this eliminates recall bias. Register studies also minimise the selection bias. In this study, however, only women born in Sweden were included and this could have led to bias in the selection of women, since women born in other countries who later gave birth in Sweden were not included.

When it comes to a cohort study concerning medication, we do not know the adherence to the prescribed medication. This creates a degree of uncertainty around medication exposure during pregnancy in studies using linked administrative data. A Swedish study has shown that data concerning medication use are more reliable in the MBR than the PDR (136). Nonadherence to medication use may result in misclassification bias, where some women classified as exposed were, in fact, not exposed during pregnancy. This misclassification has a significant potential to underestimate 
any real associations between that exposure and the investigated outcome (137). Regarding medication use there is also the issue of duration of the use and whether the pregnant women used other medications that could have had an impact on the outcomes.

In all observational studies confounding factors are a major source of bias. The use of register data makes it possible to adjust for large numbers of potential confounders. However, there is always the possibility that confounders such as life style factors, which cannot be found using register data, may have been included in the models.

One limitation with Study III was that we were unable to obtain sub-groups of N06. This ATC code also contains attention deficit hyperactivity disorder (ADHD) drugs and anti-dementia drugs. However, to be included in this study the women had to have a prescription for psychoanaleptics in combination with a depression diagnosis from specialised health care, which should minimise the risk of psychoanaleptic medication for other psychiatric conditions than MDD.

\section{Study IV}

Study IV was a naturalistic pharmacokinetic study. A naturalistic study is a nonexperimental, primarily qualitative research method in which participants are studied in their natural settings (138). By studying the doseadjusted concentrations of antidepressant drugs several times throughout pregnancy in a number of women, we wanted to find out whether the serum concentration changed in any way during pregnancy. Since this study was performed in a naturalistic setting, the blood samples were not drawn at exact predefined time points in relation to gestational length which would have been preferable but not feasible.

In the study 81 women were included at the beginning of their pregnancies and 42 women continued their antidepressant treatment throughout the pregnancy. The original intention was to include 100 pregnant women, but because of recruiting difficulties this was not possible. Additionally, there was a drop-out for women who had a miscarriage, for women who discontinued their antidepressant medication or for women who no longer wished to participate. All of these reasons for not continuing the study were expected.

The first blood samples were collected around gw 11 when several weeks of the pregnancy had already passed. Many of the physiological and 
biochemical changes in the pregnant woman's body, which could have an impact on the pharmacokinetics of a drug, begin shortly after conception. Therefore, it would have been of interest to include the women before pregnancy and also in even earlier pregnancy to study whether this would have had an impact on the results. In the escitalopram, mirtazapine and venlafaxine groups too few women were included to be able to calculate any significance. By including more women with these drugs in the study, the findings for these groups might have had more credibility.

\section{DISCUSSION OF FINDINGS IN STUDIES I-IV AND CLINICAL IMPLICATIONS}

\section{Study I}

In Study I we found that almost half of the pregnant women used medication at least once a month and that one fifth of them used medication daily to several times a week. This is a lower prevalence than previous studies $(2,3)$; however, these studies reported drug use at least once during pregnancy whereas the women in our study where asked if they used medication at least once a month or more rarely/never. The women in Study I were also asked about medication use when there was still around 10-15 weeks left of the pregnancy. The important clinical finding, though is that almost $20 \%$ used medication daily to several times a week. The majority of pregnant women perceived medication use of during pregnancy as harmful or probably harmful and it is therefore very important to ask the pregnant woman about her attitude towards medication use when prescribing any kind of medication. These findings show the significance of conducting studies concerning pregnant women's perceptions about medication use in order to counsel them in the most qualified way. As expected $(19,20)$ many of the women had changed their perception about medication use and refrained from medication to a higher degree during pregnancy compared with when they were not pregnant. Another important clinical finding was that almost $40 \%$ of the women who had been prescribed an antidepressant medication reported they had not taken it even though they claimed they had need of it. This is meaningful information for physicians and midwives working with pregnant women, especially when the pregnant woman have some kind of condition where the adherence to the prescribed medication is of the utmost importance. In this study pregnant women had high confidence in advice 
from physicians and midwives which allows for individual counselling based on e.g. age, education and parity which could lead to higher adherence to the medication.

\section{Study II}

One other study with similar methodology have been published In an exploratory study, screening of 52 serum samples through TOF-MS, detected medications in only $35 \%$ of pregnant women who, according to a web-based questionnaire and/or pharmacy records, used medication on the date of sampling. However, all medications detected in the serum samples were reported in the questionnaire (139). This is in line with our study where a high agreement was observed between questionnaire and serum screening medications taken for chronic conditions. Even though pregnant women can be hesitant towards medication as shown in Study I, the reliability of reported data for medication use for chronic diseases is high.

\section{Study III}

Several studies have reported the increased risk for adverse neonatal outcomes after maternal antidepressant medication use. However one must also take into consideration the elevated risks for both the mother and child of untreated maternal depression.

In this study we have shown that the risk of adverse obstetric and neonatal outcomes are higher regardless if the depressed woman discontinue their antidepressant medication during pregnancy or not. Regarding the actual difference in days and grams when it comes to PTB and LBW the differences are low. The risk for NICU-admission is higher in both the "Before pregnancy" and "Before and During Pregnancy" compared to population controls. These results are similar to other studies (97) who found no clear evidence that either antidepressant medication or untreated depression were more likely than the other to increase the risk of PTB, LBW or other adverse pregnancy outcomes. In this study we have shown that concerns about PTB, LBW or NICU admission are not a reason for discontinuation of antidepressant medication but rather eventual discontinuation have to depend on the pregnant woman's psychiatric health. These results are important when counselling women about their antidepressant medication treatment during pregnancy. 


\section{Study IV}

This study is unique in the sense that the concentrations of antidepressant drugs in a large number of pregnancies were studied prospectively.

Our main findings were that the dose-corrected serum concentrations of sertraline, citalopram and their respective metabolites did not change during the pregnancy period. Levels of escitalopram, venlafaxine and mirtazapine also appeared to remain stable throughout the pregnancies, but the interindividual variance in plasma levels of the drugs studied was high. Our findings provide no support of increasing doses of antidepressant drugs in the third trimester because of a presumed decrease in plasma levels of the drugs due to an increased $\mathrm{V}_{\mathrm{d}}$. The $\mathrm{U} / \mathrm{M}$ ratio values obtained were in accordance with previous studies (139-146) but our sample sizes for sertraline and citalopram were much larger. The notably high concentration of venlafaxine as well as its metabolite $\mathrm{N}$-desmethylvenlafaxine in the CYP2D6 PM woman raises a concern as do the high concentrations in cord blood. Furthermore, for the metabolite of didesmetylvenlafaxine, the U/M ratio was twice as high in the PM woman as in the other two pairs included in the study.

The study indicates a possible link between enzymatic activity, phenotypic or genetic, of CYP2D6 and exposure to venlafaxine in utero. This lends support to therapeutic drug monitoring during pregnancy, especially for venlafaxine, to maximise the potential effectiveness of the drug treatment, while minimising the potential risk of toxicity for the mother and the foetus. This should be carried out in combination with clinical monitoring of the psychiatric status of the pregnant woman. In some cases genotyping might be of value.

In conclusion this thesis provides important knowledge about pregnant women's perception of medication use during pregnancy and also provides more information regarding depression and antidepressant medication in pregnant women. In the clinical setting this could lead to better counselling for pregnant women concerning medications. 


\section{CONCLUSIONS}

Based on the studies included in this thesis the following conclusions may be drawn:

- The majority of pregnant women consider the use of medication during pregnancy as either "probably harmful" or "harmful" and this perception is associated with non-use of medication. (Study I)

- Pregnant women have high confidence in health care professionals when seeking advice. (Study I)

- The self-reporting of drug use by pregnant women seems to be reliable. There was a good coherence between reported drug intake and the drugs found in the plasma samples, which in turn positively validated the MBR. (Study II)

- Women with major depression and antidepressant medication prior to becoming pregnant are at increased risk for adverse obstetric and neonatal outcomes compared with women without major depression. (Study III)

- Continuation of antidepressant medication during pregnancy does not alter the increased risk for adverse obstetric and neonatal outcomes. (Study III)

- Plasma levels of sertraline and citalopram do not appear to change during pregnancy, but the inter-individual variance in plasma levels of the drugs is high. (Study IV)

- Therapeutic drug monitoring could be of value in the management of antidepressant treatment during pregnancy. (Study IV)

- There is a possible link between the enzymatic activity of CYP2D6 and exposure to venlafaxine in utero. (Study IV) 


\section{FUTURE PERSPECTIVES}

Study 2 is a pilot study; in the future it would be of interest to carry out a larger follow-up study with more women included. It would also be interesting to make a comparison between the drugs found in the blood of pregnant women and the drugs noted in the antenatal medical record at a later stage of the pregnancy, to see if this result differs from the results in Study 2 .

Another mental disorder that is occurring increasingly frequently is ADHD, for which medications are used by increasing numbers of reproductive-age women. The safety of drug treatment for pregnant women with ADHD and also its impact on maternal and neonatal outcomes, has not been well described.

Follow-up of children born with high concentrations of antidepressants compared to those children born with lower concentrations, do drug concentrations have a short term and long term impact on the child?

Could therapeutic drug monitoring of antidepressant medication during pregnancy improve obstetric or neonatal outcomes as well as maternal health, by avoiding drug concentrations that are too high or too low?

For future research, to study the impact of major depression and antidepressant treatment, it would be of interest to study women born outside Sweden who later gave birth in Sweden since we know that migrant women have a higher risk for adverse maternal and neonatal outcomes $(147,148)$. 


\section{POPULÄRVETENSKAPLIG SAMMANFATTNING}

Läkemedelsanvändning under graviditet blir allt vanligare. De allra flesta kvinnor kommer att använda någon form av receptfritt läkemedel under graviditeten och omkring 60-90\% kommer få något läkemedel förskrivet under graviditeten. Vanliga läkemedel under graviditet är bl. a. smärtstillande, antibiotika, läkemedel mot illamående och antidepressiv medicinering. För en del tillstånd som $\mathrm{t}$ ex astma, diabetes och inflammatorisk tarmsjukdom är det av yttersta vikt att den gravida kvinnan använder läkemedel för att undvika försämring av sin sjukdom under graviditeten och för att minska riskerna för komplikationer under graviditeten, förlossningen samt för fostret/det nyfödda barnet. För exempelvis kvinnor som är HIV positiva är antiviral läkemedelsbehandling nödvändig för att minska överföringsriskerna av HIV till fostret.

Efter Neurosedyn skandalen på 1960-talet blev många kvinnor skeptiska till läkemedelsanvändning under graviditeten och misstänksamma till vårdpersonalens information kring läkemedel under graviditet.

Depression är en av de vanligaste sjukdomarna under graviditeten. Globalt sett är cirka $12 \%$ av gravida drabbade av depression. Självmord är en av de vanligaste dödsorsakerna hos kvinnor upp till ett år efter förlossningen $\mathrm{i}$ höginkomstländer som Sverige. Att använda antidepressiva läkemedel under graviditeten blir vanligare och den vanligaste antidepressiva läkemedelsgruppen är SSRI. I de nordiska länderna (Finland ej inräknad) använder 2-7\% av de gravida kvinnorna antidepressiv medicinering. Gravida kvinnor med depression har ett försämrat förlossnings- och barn utfall jämfört med kvinnor som inte har depression. Om detta beror på antidepressiva läkemedel eller depressionssjukdomen i sig själv är fortfarande oklart.

Syftet med dessa studier var att undersöka olika aspekter kring läkemedelsanvändning under graviditet med fokus på antidepressiva läkemedel.

I delstudie I undersöktes gravida kvinnors uppfattning om läkemedelsanvändning under graviditet. Detta gjorde via en enkätstudie med 850 gravida kvinnor. En majoritet av de gravida kvinnorna tyckte att 
läkemedelsanvändning under graviditet och amning är "troligtvis skadlig" eller "skadlig". Av de gravida kvinnorna som hade fătt antidepressiv medicinering förskrivet under graviditeten använde $40 \%$ av dem inte läkemedlet. De flesta gravida kvinnor hade stort eller ganska stort förtroende för råd från läkare och barnmorskor som jobbar inom mödrahälso- eller förlossningsvården.

I delstudien II screenades blodprover från 200 gravida kvinnor för läkemedel. Resultatet jämfördes med angivna läkemedel i mödrahälsovårdsjournalerna. Uppgifter om läkemedelsanvändning i mödrahälsovårdsjournaler för alla gravida kvinnor i Sverige rapporteras vidare till det nationella medicinska födelseregistret. Många studier, såväl svenska som internationella, angående medicinering under graviditet och eventuella negativa effekter på fostret är baserade på uppgifter från det svenska medicinska födelseregistret. Vi fann en stor överrensstämmelse mellan rapporterad läkemedelsanvändning och vilka läkemedel som hittades i screeningen av blodproverna. Detta i sin tur kan sägas validera de uppgifter kring läkemedelsanvändning som finns i det medicinska födelseregistret. Delstudie III är en cohortstudie med 262329 kvinnor och deras barn. Genom att sammanlänka information från flera nationella register undersökte förlossnings- och barnutfall hos kvinnor med antidepressiv läkemedelsanvändning plus depressionsdiagnos före och/eller under graviditet. Dessa grupper jämfördes också med en kontrollgrupp som varken hade depressionsdiagnos eller använde antidepressiva läkemedel. I den här studien fann vi att de kvinnor som använde eller hade använt antidepressiva läkemedel hade en ökad risk för negativa förlossningsutfall som instrumentell förlossning och kejsarsnitt eller negativt neonatalt utfall som för tidig födsel och låg födelsevikt. Risken för dessa utfall ökade något om den gravida kvinnan fortsatte med antidepressiva läkemedel under graviditeten.

I delstudie IV undersöktes de dosjusterade läkemedelskoncentrationerna hos 81 gravida kvinnor under hela graviditeten fram tills förlossning. Koncentrationerna av sertralin och citalopram förändrades inte signifikant under graviditeten. Koncentrationerna av escitalopram, mirtazapin samt venlafaxin verkar heller inte förändras under graviditeten.

Sammanfattningsvis kan den här avhandlingen bidra till att öka förståelsen kring gravida kvinnors uppfattning kring läkemedelsbehandling samt bidra 
med mer kunskap kring depression och antidepressiv medicinering hos gravida kvinnor. 


\section{ACKNOWLEDGEMENTS}

I would like to thank everyone that has given their support and inspiration during my years of doctoral studies, and especially:

Professor Ann Josefsson, my main supervisor for introducing me to the world of research, for always encouraging me and for all your sage advice throughout the years.

Associate professor Caroline Lilliecreutz, my co-supervisor for your inspiration and encouragement, both in the clinical and the scientific setting.

Associate professor Margareta Reis, my co-supervisor for all your positive support, and for your knowledge when introducing me to the field of pharmacokinetics.

Marie Bladh, for your invaluable help with statistics and for answering all my statistically related questions, however basic.

Lotta Lindh-Åstrand for all your help and input in Study 1 .

Martin Josefsson for both practical and theoretical help in Study 2.

My co-authors in Study 4, Dr Erik Nilzén and Anna-Lena Zackrisson.

All women participating in Study 1, 2 and 4 and all personnel who helped with these studies, the studies would not have been possible without you.

Professor Preben Kjölhede, Professor Gunilla Sydsjö, Dr Sofia Pihl, Dr Kristina Kernell, Dr Sara Carlhäll and associate professor Anna-Clara Spetz Holm, for taking the time to review my manuscripts and thesis and providing me with very useful feed-back. And Gunilla for valuable help and knowledge in Study 3. 
Associate professor Elizabeth Nedstrand, head of Department of Obstetrics and Gynaecology in Linköping, Dr Kristina Kernell, Dr Anna Karlsson and Dr Sofia Pihl for giving me time and opportunity to complete this thesis even in these different times.

All friends and colleagues at the Department of Obstetrics and Gynaecology in Linköping at the University Hospital in Linköping for making work both interesting and fun. Thank you Sofia, Madelene, Agota and Anna for your fabulous company on the resident/PhD student journey.

My dear friends, thanks for your support and for cheering me on. I am so grateful for you all. Especially, thank you Ida for being my sounding board $24 / 7$.

My family for loving support, always. My mother and father, thank you for always being there. My brother Erik, thank you for all encouragement and especially thank you for all Word and Excel related help. My grandmother Karin. My sister-in-law Madeleine and of course Ellen and Philip. 


\section{REFERENCES}

1. Mitchell AA, Gilboa SM, Werler MM, Kelley KE, Louik C, Hernández-Díaz S; National Birth Defects Prevention Study. Medication use during pregnancy, with particular focus on prescription drugs: 1976-2008. Am J Obstet Gynecol. 2011 Jul;205(1):51.e1-8. doi: 10.1016/j.ajog.2011.02.029. Epub 2011 Apr 22. PMID: 21514558; PMCID: PMC3793635

2. de Waard M, Blomjous BS, Hol MLF, Sie SD, Corpeleijn WE, van Goudoever JHB, van Weissenbruch MM. Medication Use During Pregnancy and Lactation in a Dutch Population. J Hum Lact. 2019 Feb;35(1):154-164. doi: 10.1177/0890334418775630. Epub 2018 Jul 3. PMID: 29969343.

3. Haas DM, Marsh DJ, Dang DT, Parker CB, Wing DA, Simhan HN, Grobman WA, Mercer BM, Silver RM, Hoffman MK, Parry S, Iams JD, Caritis SN, Wapner RJ, Esplin MS, Elovitz MA, Peaceman AM, Chung J, Saade GR, Reddy UM. Prescription and Other Medication Use in Pregnancy. Obstet Gynecol. 2018 May;131(5):789-798. doi: 10.1097/AOG.0000000000002579. PMID: 29630018; PMCID: PMC5912972.

4. Bérard A, Abbas-Chorfa F, Kassai B, Vial T, Nguyen KA, Sheehy O, Schott AM. The French Pregnancy Cohort: Medication use during pregnancy in the French population. PLoS One. 2019 Jul 17;14(7):e0219095. doi: 10.1371/journal.pone.0219095. PMID: 31314794; PMCID: PMC6636733.

5. Engeland A, Bjørge T, Klungsøyr K, Hjellvik V, Skurtveit S, Furu K. Trends in prescription drug use during pregnancy and postpartum in Norway, 2005 to 2015. Pharmacoepidemiol Drug Saf. 2018 Sep;27(9):995-1004. doi: 10.1002/pds.4577. Epub 2018 Jun 19. PMID: 29920833.

6. Leong C, Chateau D, Dahl M, Falk J, Katz A, Bugden S, Raymond C. Prescription medication use during pregnancies that resulted in births and abortions (2001-2013): A retrospective population-based study in a Canadian population. PLoS One. 2019 Mar 6;14(3):e0211319. doi: 10.1371/journal.pone.0211319. PMID: 30840711; PMCID: PMC6402756.

7. Lupattelli A, Spigset O, Twigg MJ, Zagorodnikova K, Mårdby AC, Moretti ME, Drozd M, Panchaud A, Hämeen-Anttila K, Rieutord A, Gjergja Juraski R, Odalovic M, Kennedy D, Rudolf G, Juch H, Passier A, Björnsdóttir I, Nordeng H. Medication use in pregnancy: a crosssectional, multinational web-based study. BMJ Open. 2014 Feb 17;4(2):e004365. doi: 10.1136/bmjopen-2013-004365. PMID: 24534260; PMCID: PMC3927801.

8. Palmsten K, Hernández-Díaz S, Chambers CD, Mogun H, Lai S, Gilmer TP, Huybrechts KF. The Most Commonly Dispensed Prescription Medications Among Pregnant Women Enrolled in the U.S. Medicaid Program. Obstet Gynecol. 2015 Sep;126(3):465-73. doi: 10.1097/AOG.0000000000000982. PMID: 26244530; PMCID: PMC4651654

9. Clowse ME. Lupus activity in pregnancy. Rheum Dis Clin North Am. 2007 May;33(2):237-52.

10. Tubiana R, Le Chenadec J, Rouzioux C, Mandelbrot L, Hamrene K, Dollfus C, et al. Factors associated with mother-to-child transmission of HIV-1 despite a maternal viral load $<500$ copies/ml at delivery: a case-control study nested in the French perinatal cohort (EPF-ANRS CO1). Clin Infect Dis. 2010 Feb 15;50(4):585-96.

11. Petersen I, McCrea RL, Lupattelli A, Nordeng H. Women's perception of risks of adverse fetal pregnancy outcomes: a large-scale multinational survey. BMJ Open. 2015;5(6):e007390.

12. Amundsen S, Øvrebø TG, Amble NMS, Poole AC, Nordeng H. Risk perception, beliefs about medicines and medical adherence among pregnant and breastfeeding women with migraine: findings from a cross-sectional study in Norway. BMJ Open. 2019 Feb 27;9(2):e026690. doi: 10.1136/bmjopen-2018-026690. PMID: 30819714; PMCID: PMC6398664.

13. Undela K, Joy N, Gurumurthy P, M S S. Knowledge, beliefs, and practice of pregnant women regarding medication use during pregnancy: a hospital-based cross-sectional study. J Obstet Gynaecol. 2020 Jun 18:1-5. doi: 10.1080/01443615.2020.1754368. Epub ahead of print. PMID: 32552304.

14. Lupattelli A, Spigset O, Nordeng H. Adherence to medication for chronic disorders during pregnancy: results from a multinational study. Int J Clin Pharm. 2014 Feb;36(1):145-53. doi: 10.1007/s11096-013-9864-y. Epub 2013 Oct 27. PMID: 24162929. 
15. Nyholm RS, Andersen JT, Vermehren C, Kaae S. Perceptions of medicine use among pregnant women: an interview-based study. Int J Clin Pharm. 2019 Aug;41(4):1021-1030. doi: 10.1007/s11096-019-00840-4. Epub 2019 May 18. PMID: 31104187. (a)

16. Ceulemans M, Van Calsteren K, Allegaert K, Foulon V. Beliefs about medicines and information needs among pregnant women visiting a tertiary hospital in Belgium. Eur J Clin Pharmacol. 2019 Jul;75(7):995-1003. doi: 10.1007/s00228-019-02653-w. Epub 2019 Mar 4. PMID: 30834472.

17. Lupattelli A, Picinardi M, Cantarutti A, Nordeng H. Use and Intentional Avoidance of Prescribed Medications in Pregnancy: A Cross-Sectional, Web-Based Study among 926 Women in Italy. Int J Environ Res Public Health. 2020 May 28;17(11):3830. doi: 10.3390/ijerph17113830. PMID: 32481641; PMCID: PMC7312729.

18. Navaro M, Vezzosi L, Santagati G, Angelillo IF; Collaborative Working Group. Knowledge, attitudes, and practice regarding medication use in pregnant women in Southern Italy. PLoS One. 2018 Jun 19;13(6):e0198618. 10.1371/journal.pone.0198618. PMID: 29920515; PMCID: PMC6007931.

19. Nordeng H, Koren G, Einarson A. Pregnant women's beliefs about medications--a study among 866 Norwegian women. Ann Pharmacother. 2010 Sep;44(9):1478-84. doi: 10.1345/aph.1P231. Epub 2010 Aug 24. PMID: 20736425.

20. Twigg MJ, Lupattelli A, Nordeng H. Women's beliefs about medication use during their pregnancy: a UK perspective. Int J Clin Pharm. 2016 Aug;38(4):968-76. doi: 10.1007/s11096016-0322-5. Epub 2016 May 30. PMID: 27241342; PMCID: PMC4929153.

21. Zaki NM, Albarraq AA. Use, attitudes and knowledge of medications among pregnant women: A Saudi study. Saudi Pharm J. 2014 Nov;22(5):419-28. doi: 10.1016/j.jsps.2013.09.001. Epub 2013 Oct 23. PMID: 25473330; PMCID: PMC4246410.

22. Nyholm RS, Andersen JT, Vermehren C, Kaae S. Perceptions of medicine use among pregnant women: an interview-based study. Int J Clin Pharm. 2019 Aug;41(4):1021-1030. doi: 10.1007/s11096-019-00840-4. Epub 2019 May 18. PMID: 31104187.

23. Costantine MM. Physiologic and pharmacokinetic changes in pregnancy. Front Pharmacol. 2014 Apr 3;5:65. doi: 10.3389/fphar.2014.00065. PMID: 24772083; PMCID: PMC3982119.

24. Pariente G, Leibson T, Carls A, Adams-Webber T, Ito S, Koren G. Pregnancy-Associated Changes in Pharmacokinetics: A Systematic Review. PLoS Med. 2016 Nov 1;13(11):e1002160. doi: 10.1371/journal.pmed.1002160. PMID: 27802281; PMCID: PMC5089741

25. Koren G, Pariente G. Pregnancy- Associated Changes in Pharmacokinetics and their Clinical Implications. Pharm Res. 2018;35(3):61. Published 2018 Feb 12. doi:10.1007/s11095-018-23522

26. Dawes M, Chowienczyk PJ. Drugs in pregnancy. Pharmacokinetics in pregnancy. Best Pract Res Clin Obstet Gynaecol. 2001 Dec;15(6):819-26. doi: 10.1053/beog.2001.0231. PMID: 11800526

27. .Loebstein R, Lalkin A, Koren G. Pharmacokinetic changes during pregnancy and their clinical relevance. Clin Pharmacokinet. 1997 Nov;33(5):328-43. doi: 10.2165/00003088-19973305000002. PMID: 9391746.

28. Tasnif Y, Morado J, Hebert MF. Pregnancy-related pharmacokinetic changes. Clin Pharmacol Ther. 2016 Jul;100(1):53-62. doi: 10.1002/cpt.382. Epub 2016 May 14. PMID: 27082931

29. Anderson, G.D. Pregnancy-induced changes in pharmacokinetics: a mechanistic-based approach. Clin Pharmacokinet, 2005. 44(10): p. 989-1008.

30. McDonnell AM, Dang CH. Basic review of the cytochrome p450 system. J Adv Pract Oncol. 2013 Jul;4(4):263-8. doi: 10.6004/jadpro.2013.4.4.7. PMID: 25032007; PMCID: PMC4093435.

31. Zanger UM, Schwab M. Cytochrome P450 enzymes in drug metabolism: regulation of gene expression, enzyme activities, and impact of genetic variation. Pharmacol Ther. 2013 Apr;138(1):103-41. doi: 10.1016/j.pharmthera.2012.12.007. Epub 2013 Jan 16. PMID: 23333322.

32. Koren G, Ornoy A. Clinical implications of selective serotonin reuptake inhibitors-selective serotonin norepinephrine reuptake inhibitors pharmacogenetics during pregnancy and lactation. Pharmacogenomics. 2018 Sep 1;19(14):1139-1145. doi: 10.2217/pgs-2018-0076. Epub 2018 Aug 14. PMID: 30105921.

33. Hicks JK, Bishop JR, Sangkuhl K, Müller DJ, Ji Y, Leckband SG, Leeder JS, Graham RL, Chiulli DL, LLerena A, Skaar TC, Scott SA, Stingl JC, Klein TE, Caudle KE, Gaedigk A; 
Clinical Pharmacogenetics Implementation Consortium. Clinical Pharmacogenetics Implementation Consortium (CPIC) Guideline for CYP2D6 and CYP2C19 Genotypes and Dosing of Selective Serotonin Reuptake Inhibitors. Clin Pharmacol Ther. 2015 Aug;98(2):12734. doi: 10.1002/cpt.147. Epub 2015 Jun 29. PMID: 25974703; PMCID: PMC4512908.

34. Deligiannidis KM, Byatt N, Freeman MP. Pharmacotherapy for mood disorders in pregnancy: a review of pharmacokinetic changes and clinical recommendations for therapeutic drug monitoring. J Clin Psychopharmacol. 2014 Apr;34(2):244-55. doi: 10.1097/JCP.0000000000000087. PMID: 24525634; PMCID: PMC4105343.

35. Lopes van Balen VA, van Gansewinkel TAG, de Haas S, et al. Maternal kidney function during pregnancy: systematic review and meta-analysis. Ultrasound Obstet Gynecol. 2019;54(3):297307. doi:10.1002/uog.20137011 Feb 1;3:43-50. doi: 10.2147/CLEP.S16305. PMID: 21386973; PMCID: PMC3046184.

36. Weissman MM, Olfson M. Depression in women: implications for health care research. Science. 1995 Aug 11;269(5225):799-801. doi: 10.1126/science.7638596. PMID: 7638596.

37. Brummelte S, Galea LA. Postpartum depression: Etiology, treatment and consequences for maternal care. Horm Behav. 2016 Jan;77:153-66. doi: 10.1016/j.yhbeh.2015.08.008. Epub 2015 Aug 28. PMID: 26319224.

38. GBD 2016 Disease and Injury Incidence and Prevalence Collaborators. Global, regional, and national incidence, prevalence, and years lived with disability for 328 diseases and injuries for 195 countries, 1990-2016: a systematic analysis for the Global Burden of Disease Study 2016. Lancet. 2017 Sep 16;390(10100):1211-1259. doi: 10.1016/S0140-6736(17)32154-2. Erratum in: Lancet. 2017 Oct 28;390(10106):e38. PMID: 28919117; PMCID: PMC5605509.

39. Uher R, Payne JL, Pavlova B, Perlis RH. Major depressive disorder in DSM-5: implications for clinical practice and research of changes from DSM-IV. Depress Anxiety. 2014 Jun;31(6):45971. doi: 10.1002/da.22217. Epub 2013 Nov 22. PMID: 24272961

40. Montgomery S. Are the ICD-10 or DSM-5 diagnostic systems able to define those who will benefit from treatment for depression? CNS Spectr. 2016 Aug;21(4):283-8. doi: 10.1017/S1092852916000389. Epub 2016 Jul 15. PMID: 27418397.

41. Socialstyrelsen. Kodning inom psykiatrin. [Internet] Stockholm; 2019. [Updated 30 Aug 2019; cited 20 Oct 2020]. Available from: https://www.socialstyrelsen.se/utveckla-verksamhet/ehalsa/klassificering-och-koder/icd-10/psykiatrikoder/

42. Biaggi A, Conroy S, Pawlby S, Pariante CM. Identifying the women at risk of antenatal anxiety and depression: A systematic review. J Affect Disord. 2016 Feb;191:62-77. doi: 10.1016/j.jad.2015.11.014. Epub 2015 Nov 18. PMID: 26650969; PMCID: PMC4879174.

43. Gaynes BN, Gavin N, Meltzer-Brody S, Lohr KN, Swinson T, Gartlehner G, Brody S, Miller WC. Perinatal depression: prevalence, screening accuracy, and screening outcomes. Evid Rep Technol Assess (Summ). 2005 Feb;(119):1-8. doi: 10.1037/e439372005-001. PMID: 15760246; PMCID: PMC4780910.

44. Yonkers KA, Smith MV, Gotman N, Belanger K. Typical somatic symptoms of pregnancy and their impact on a diagnosis of major depressive disorder. Gen Hosp Psychiatry. 2009 JulAug;31(4):327-33. doi: 10.1016/j.genhosppsych.2009.03.005. Epub 2009 Apr 15. PMID: 19555792; PMCID: PMC2748743.

45. National Institute for Health and Care Excellence. Antenatal and postnatal mental health: clinical management and service guidance [Internet]. [London]: NICE; 2014 [Updated: 11 February 2020; cited 2020 Oct 11]. (Clinical guideline [CG192]). Available from: https://www.nice.org.uk/guidance/cg192/chapter/1Recommendations

46. Arbets- och Referensgruppen för Psykosocial Obstetrik och Gynekologi samt Sexologi Nr 622009 Barnafödande och psykisk sjukdom [Internet] (Cited 11 Oct 2020). Available from: https://www.sfog.se/natupplaga/ARG76web43658b6c2-849e-47ab-99fa-52e8ac993b7d.pdf

47. Cox JL, Holden JM, Sagovsky R. Detection of postnatal depression. Development of the 10-item Edinburgh Postnatal Depression Scale. Br J Psychiatry. 1987 Jun;150:782-6. doi: 10.1192/bjp.150.6.782. PMID: 3651732.

48. Venkatesh KK, Nadel H, Blewett D, Freeman MP, Kaimal AJ, Riley LE. Implementation of universal screening for depression during pregnancy: feasibility and impact on obstetric care. Am J Obstet Gynecol. 2016 Oct;215(4):517.e1-8. doi: 10.1016/j.ajog.2016.05.024. Epub 2016 May 20. PMID: 27210067. 
49. Rubertsson C, Börjesson K, Berglund A, Josefsson A, Sydsjö G. The Swedish validation of Edinburgh Postnatal Depression Scale (EPDS) during pregnancy. Nord J Psychiatry. 2011 Dec;65(6):414-8. doi: 10.3109/08039488.2011.590606. Epub 2011 Jul 5. PMID: 21728782.

50. Woody CA, Ferrari AJ, Siskind DJ, Whiteford HA, Harris MG. A systematic review and metaregression of the prevalence and incidence of perinatal depression. J Affect Disord. 2017 Sep;219:86-92. doi: 10.1016/j.jad.2017.05.003. Epub 2017 May 8. PMID: 28531848.

51. Dadi AF, Miller ER, Bisetegn TA, Mwanri L. Global burden of antenatal depression and its association with adverse birth outcomes: an umbrella review. BMC Public Health. $2020 \mathrm{Feb}$ 4;20(1):173. doi: 10.1186/s12889-020-8293-9. PMID: 32019560; PMCID: PMC7001252.

52. Esscher A, Essén B, Innala E, Papadopoulos FC, Skalkidou A, Sundström-Poromaa I, Högberg U. Suicides during pregnancy and 1 year postpartum in Sweden, 1980-2007. Br J Psychiatry. 2016 May;208(5):462-9. doi: 10.1192/bjp.bp.114.161711. Epub 2015 Oct 22. PMID: 26494874.

53. Lysell H, Dahlin M, Viktorin A, Ljungberg E, D'Onofrio BM, Dickman P, Runeson B. Maternal suicide - Register based study of all suicides occurring after delivery in Sweden 1974-2009. PLoS One. 2018 Jan 5;13(1):e0190133. doi: 10.1371/journal.pone.0190133. PMID: 29304045; PMCID: PMC5755764.

54. Räisänen S, Lehto SM, Nielsen HS, Gissler M, Kramer MR, Heinonen S. Risk factors for and perinatal outcomes of major depression during pregnancy: a population-based analysis during 2002-2010 in Finland. BMJ Open. 2014 Nov 14;4(11):e004883. doi: 10.1136/bmjopen-2014004883. PMID: 25398675; PMCID: PMC4244456.

55. Wikman A, Axfors C, Iliadis SI, Cox J, Fransson E, Skalkidou A. Characteristics of women with different perinatal depression trajectories. J Neurosci Res. 2020 Jul;98(7):1268-1282. doi: 10.1002/jnr.24390. Epub 2019 Feb 5. PMID: 30723972.

56. Bunney WE Jr, Davis JM. Norepinephrine in depressive reactions. A review. Arch Gen Psychiatry. 1965 Dec;13(6):483-94. doi: 10.1001/archpsyc.1965.01730060001001. PMID: 5320621.

57. Schildkraut JJ. The catecholamine hypothesis of affective disorders: a review of supporting evidence. Am J Psychiatry. 1965 Nov;122(5):509-22. doi: 10.1176/ajp.122.5.509. PMID: 5319766.

58. López-Muñoz F, Alamo C. Monoaminergic neurotransmission: the history of the discovery of antidepressants from 1950s until today. Curr Pharm Des. 2009;15(14):1563-86. doi: 10.2174/138161209788168001. PMID: 19442174.

59. Sánchez C, Hyttel J. Comparison of the effects of antidepressants and their metabolites on reuptake of biogenic amines and on receptor binding. Cell Mol Neurobiol. 1999 Aug;19(4):46789. doi: 10.1023/a:1006986824213. PMID: 10379421.

60. Wong DT, Horng JS, Bymaster FP, Hauser KL, Molloy BB. A selective inhibitor of serotonin uptake: Lilly 110140, 3-(p-trifluoromethylphenoxy)-N-methyl-3-phenylpropylamine. Life Sci. 1974 Aug 1;15(3):471-9. doi: 10.1016/0024-3205(74)90345-2. PMID: 4549929.

61. Alwan S, Friedman JM, Chambers C. Safety of Selective Serotonin Reuptake Inhibitors in Pregnancy: A Review of Current Evidence. CNS Drugs. 2016 Jun;30(6):499-515

62. Ables AZ, Baughman OL 3rd. Antidepressants: update on new agents and indications. Am Fam Physician. 2003 Feb 1;67(3):547-54.

63. Ellingrod VL, Perry PJ. Venlafaxine: a heterocyclic antidepressant. Am J Hosp Pharm. 1994 Dec 15;51(24):3033-46. PMID: 7856622.

64. Charlton RA, Jordan S, Pierini A, Garne E, Neville AJ, Hansen AV, Gini R, Thayer D, Tingay K, Puccini A, Bos HJ, Nybo Andersen AM, Sinclair M, Dolk H, de Jong-van den Berg LT. Selective serotonin reuptake inhibitor prescribing before, during and after pregnancy: a population-based study in six European regions. BJOG. 2015 Jun;122(7):1010-20. doi: 10.1111/1471-0528.13143. Epub 2014 Oct 28. PMID: 25352424.

65. Liang OS, Sheffield JS, Taylor CO. Detecting Patterns of Prescription Drug Use During Pregnancy and Lactation with Visualization Techniques. AMIA Jt Summits Transl Sci Proc. 2019 May 6;2019:478-487. PMID: 31259002; PMCID: PMC6568088.

66. Molenaar NM, Lambregtse-van den Berg MP, Bonsel GJ. Dispensing patterns of selective serotonin reuptake inhibitors before, during and after pregnancy: a 16-year population-based cohort study from the Netherlands. Arch Womens Ment Health. 2020;23(1):71-79. doi:10.1007/s00737-019-0951-5 
67. Petersen JM, Esposito DB, Werler MM. Selective serotonin reuptake inhibitor use patterns among commercially insured US pregnancies (2005-2014). Arch Womens Ment Health. 2020 Mar 28. doi: 10.1007/s00737-020-01027-x. Epub ahead of print. PMID: 32222834.

68. O’Connor EA, Senger CA, Henninger M, Gaynes BN, Coppola E, Soulsby Weyrich M. Interventions to prevent perinatal depression: a systematic evidence review for the U.S. preventive services task force. Evidence synthesis no. 172. AHRQ publication no 18-05243-EF1. Rockville, MD: Agency for Healthcare Research and Quality; 2019.

69. Howard LM, Megnin-Viggars O, Symington I, Pilling S; Guideline Development Group. Antenatal and postnatal mental health: summary of updated NICE guidance. BMJ. 2014 Dec 18;349:g7394. doi: 10.1136/bmj.g7394. PMID: 25523903.

70. Andrade SE, Raebel MA, Brown J, Lane K, Livingston J, Boudreau D, et al. Use of antidepressant medications during pregnancy: A multisite study. Am J Obstet Gynecol. 2008;198(2):194.e1194.e1945. doi:10.1016/j.ajog.2007.07.036

71. Petersen I, Gilbert RE, Evans SJ, Man SL, Nazareth I. Pregnancy as a major determinant for discontinuation of antidepressants: an analysis of data from The Health Improvement Network. J Clin Psychiatry. 2011 Jul;72(7):979-85. doi: 10.4088/JCP.10m06090blu. Epub 2011 Mar 8. PMID: 21457681.

72. Molenaar NM, Bais B, Lambregtse-van den Berg MP, Mulder CL, Howell EA, Fox NS, Rommel AS, Bergink V, Kamperman AM. The international prevalence of antidepressant use before, during, and after pregnancy: A systematic review and meta-analysis of timing, type of prescriptions and geographical variability. J Affect Disord. 2020 Mar 1;264:82-89. doi: 10.1016/j.jad.2019.12.014. Epub 2019 Dec 9. PMID: 31846905.

73. Zoega H, Kieler H, Nørgaard M, Furu K, Valdimarsdottir U, Brandt L, Haglund B. Use of SSRI and SNRI Antidepressants during Pregnancy: A Population-Based Study from Denmark, Iceland, Norway and Sweden. PLoS One. 2015 Dec 14;10(12):e0144474. doi: 10.1371/journal.pone.0144474. PMID: 26657647; PMCID: PMC4685993.

74. Skalkidou A, Sundström-Poromaa I, Wikman A, Hesselman S, Wikström AK, Elenis E. SSRI use during pregnancy and risk for postpartum haemorrhage: a national register-based cohort study in Sweden. BJOG. 2020 Oct;127(11):1366-1373. doi: 10.1111/1471-0528.16210. Epub 2020 Apr 1. PMID: 32162458.

75. Bénard-Laribière A, Pambrun E, Sutter-Dallay AL, Gautier S, Hurault-Delarue C, DamaseMichel C, et al. Patterns of antidepressant use during pregnancy: a nationwide population-based cohort study. Br J Clin Pharmacol. 2018 Aug;84(8):1764-1775.

76. Ververs T, Kaasenbrood H, Visser G, Schobben F, de Jong-van den Berg L, Egberts T. Prevalence and patterns of antidepressant drug use during pregnancy. Eur J Clin Pharmacol. 2006 Oct;62(10):863-70. doi: 10.1007/s00228-006-0177-0. Epub 2006 Aug 8. PMID: 16896784.

77. Andrade SE, Reichman ME, Mott K, Pitts M, Kieswetter C, Dinatale M, Stone MB, Popovic J, Haffenreffer K, Toh S. Use of selective serotonin reuptake inhibitors (SSRIs) in women delivering liveborn infants and other women of child-bearing age within the U.S. Food and Drug Administration's Mini-Sentinel program. Arch Womens Ment Health. 2016 Dec;19(6):969-977. doi: 10.1007/s00737-016-0637-1. Epub 2016 May 13. PMID: 27178125

78. Cabaillot A, Bourset A, Mulliez A, Delorme J, Orri M, Vicard-Olagne M, Zenut MC, Tournier M, Gallot D, Authier N, Chenaf C, Laporte C. Trajectories of antidepressant drugs during pregnancy: A cohort study from a community-based sample. Br J Clin Pharmacol. 2020 Aug 4. doi: 10.1111/bcp.14449. Epub ahead of print. PMID: 32755022.

79. Hayes RM, Wu P, Shelton RC, Cooper WO, Dupont WD, Mitchel E, Hartert TV. Maternal antidepressant use and adverse outcomes: a cohort study of 228,876 pregnancies. Am J Obstet Gynecol. 2012 Jul;207(1):49.e1-9.

80. Margulis AV, Kang EM, Hammad TA. Patterns of Prescription of Antidepressants and Antipsychotics across and within pregnancies in a population-based UK cohort. Matern Child Health J. 2014 Sep;18(7):1742-52.

81. Kothari A, de Laat J, Dulhunty JM, Bruxner G. Perceptions of pregnant women regarding antidepressant and anxiolytic medication use during pregnancy. Australas Psychiatry. 2019 Apr;27(2):117-120. doi: 10.1177/1039856218810162. Epub 2018 Nov 1. PMID: 30382755.

82. Cohen LS, Altshuler LL, Harlow BL, Nonacs R, Newport DJ, Viguera AC, et al. Relapse of major depression during pregnancy in women who maintain or discontinue antidepressant 
treatment. JAMA. 2006 Feb 1;295(5):499-507. 10.1001/jama.295.5.499. Erratum in: JAMA. 2006 Jul 12;296(2):170.

83. Adhikari K, Patten SB, Lee S, Metcalfe A. Risk of adverse perinatal outcomes among women with pharmacologically treated and untreated depression during pregnancy: A retrospective cohort study. Paediatr Perinat Epidemiol. 2019;33(5):323-331.

84. Roca A, Imaz ML, Torres A, Plaza A, Subirà S, Valdés M, et al. Unplanned pregnancy and discontinuation of SSRIs in pregnant women with previously treated affective disorder. J Affect Disord. 2013 Sep 25;150(3):807-13.

85. Wikman A, Skalkidou A, Wikström AK, Lampa E, Kramer MS, Yong EL, Skoglund C, Epperson N, Sundström-Poromaa I. Factors associated with re-initiation of antidepressant treatment following discontinuation during pregnancy: a register-based cohort study. Arch Womens Ment Health. 2020 Jul 6. doi: 10.1007/s00737-020-01050-y. Epub ahead of print. PMID: 32632522.

86. Adhikari K, Patten SB, Lee S, Metcalfe A. Adherence to and Persistence with Antidepressant Medication during Pregnancy: Does It Differ by the Class of Antidepressant Medication Prescribed? Can J Psychiatry. 2019 Mar;64(3):199-208. doi: 10.1177/0706743718802809. Epub 2018 Sep 25. PMID: 30252505; PMCID: PMC6405814.

87. Bosman J, Ter Horst PG, Smit JP, Dijkstra JR, Beekhuis HR, Slingersland RJ, Hospes W. Adherence of antidepressants during pregnancy: MEMS compared with three other methods. Ther Adv Psychopharmacol. 2014 Apr;4(2):61-9. doi: 10.1177/2045125313511486. PMID: 24688757; PMCID: PMC3952485.

88. Fischer Fumeaux CJ, Morisod Harari M, Weisskopf E, Eap CB, Epiney M, Vial Y, Csajka C, Bickle Graz M, Panchaud A. Risk-benefit balance assessment of SSRI antidepressant use during pregnancy and lactation based on best available evidence - an update. Expert Opin Drug Saf. 2019 Oct;18(10):949-963. doi: 10.1080/14740338.2019.1658740. Epub 2019 Sep 9. PMID: 31430189.

89. Hu R, Li Y, Zhang Z, Yan W. Antenatal depressive symptoms and the risk of preeclampsia or operative deliveries: a meta-analysis. PLoS One. 2015 Mar 19;10(3):e0119018. doi: 10.1371/journal.pone.0119018. PMID: 25789626; PMCID: PMC4366102.

90. Malm H, Sourander A, Gissler M, Gyllenberg D, Hinkka-Yli-Salomäki S, McKeague IW, et al. Pregnancy Complications Following Prenatal Exposure to SSRIs or Maternal Psychiatric Disorders: Results From Population-Based National Register Data. Am J Psychiatry. 2015 Dec;172(12):1224-32. doi: 10.1176/appi.ajp.2015.14121575.

91. Gao SY, Wu QJ, Sun C, Zhang TN, Shen ZQ, Liu CX, et al. Selective serotonin reuptake inhibitor use during early pregnancy and congenital malformations: a systematic review and meta-analysis of cohort studies of more than 9 million births. BMC Med. 2018 Nov 12;16(1):205. doi: 10.1186/s12916-018-1193-5.

92. Zhang TN, Gao SY, Shen ZQ, Li D, Liu CX, Lv HC, Zhang Y, Gong TT, Xu X, Ji C, Wu QJ. Use of selective serotonin-reuptake inhibitors in the first trimester and risk of cardiovascularrelated malformations: a meta-analysis of cohort studies. Sci Rep. 2017 Feb 21;7:43085. doi: 10.1038/srep43085. PMID: 28220881; PMCID: PMC5318893.

93. Uguz F. Selective serotonin reuptake inhibitors and the risk of congenital anomalies anomalies: a systematic review of current meta-analyses. Expert Opin Drug Saf. 2020 Oct 12:1-10. doi: 10.1080/14740338.2020.1832080. Epub ahead of print. PMID: 33001713.

94. Kieviet N, Dolman KM, Honig A. The use of psychotropic medication during pregnancy: how about the newborn? Neuropsychiatr Dis Treat. 2013;9:1257-66. doi: 10.2147/NDT.S36394. Epub 2013 Aug 28. PMID: 24039427; PMCID: PMC3770341.

95. Muzik M, Hamilton SE. Use of Antidepressants During Pregnancy?: What to Consider when Weighing Treatment with Antidepressants Against Untreated Depression. Matern Child Health J. 2016 Nov;20(11):2268-2279. doi: 10.1007/s10995-016-2038-5. PMID: 27461022.

96. Nörby U, Forsberg L, Wide K, Sjörs G, Winbladh B, Källén K. Neonatal Morbidity After Maternal Use of Antidepressant Drugs During Pregnancy. Pediatrics. 2016 Nov;138(5).

97. Mitchell J, Goodman J. Comparative effects of antidepressant medications and untreated major depression on pregnancy outcomes: a systematic review. Arch Womens Ment Health. 2018;21(5):505-516. doi:10.1007/s00737-018-0844-z 
98. Becker M, Weinberger T, Chandy A, Schmukler S. Depression During Pregnancy and Postpartum. Curr Psychiatry Rep. 2016 Mar;18(3):32. doi: 10.1007/s11920-016-0664-7. PMID: 26879925

99. Eke AC, Saccone G, Berghella V. Selective serotonin reuptake inhibitor (SSRI) use during pregnancy and risk of preterm birth: a systematic review and meta-analysis. BJOG. 2016 Nov;123(12):1900-1907. doi: 10.1111/1471-0528.14144. Epub 2016 May 30. PMID: 27239775.

100. Osborne S, Biaggi A, Chua TE, Du Preez A, Hazelgrove K, Nikkheslat N, Previti G, Zunszain PA, Conroy S, Pariante CM. Antenatal depression programs cortisol stress reactivity in offspring through increased maternal inflammation and cortisol in pregnancy: The Psychiatry Research and Motherhood - Depression (PRAM-D) Study. Psychoneuroendocrinology. 2018 Dec;98:211221. doi: 10.1016/j.psyneuen.2018.06.017. Epub 2018 Jul 19. Erratum in: Psychoneuroendocrinology. 2020 Sep;119:104795. PMID: 30033161; PMCID: PMC6215770.

101. Mastorakos G, Ilias I. Maternal and fetal hypothalamic-pituitary-adrenal axes during pregnancy and postpartum. Ann N Y Acad Sci. 2003 Nov;997:136-49. doi: 10.1196/annals.1290.016. PMID: 14644820.

102.Rifkin-Graboi A, Bai J, Chen H, Hameed WB, Sim LW, Tint MT, Leutscher-Broekman B, Chong YS, Gluckman PD, Fortier MV, Meaney MJ, Qiu A. Prenatal maternal depression associates with microstructure of right amygdala in neonates at birth. Biol Psychiatry. 2013 Dec 1;74(11):837-44. doi: 10.1016/j.biopsych.2013.06.019. Epub 2013 Aug 19. PMID: 23968960.

103. Stewart DE, Vigod S. Postpartum Depression. N Engl J Med. 2016 Dec 1;375(22):2177-2186. doi: 10.1056/NEJMcp1607649. PMID: 27959754.

104.Stewart DE, Vigod SN. Postpartum Depression: Pathophysiology, Treatment, and Emerging Therapeutics. Annu Rev Med. 2019 Jan 27;70:183-196. doi: 10.1146/annurev-med-041217011106. PMID: 30691372.

105.Heron J, O'Connor TG, Evans J, Golding J, Glover V; ALSPAC Study Team. The course of anxiety and depression through pregnancy and the postpartum in a community sample. J Affect Disord. 2004 May;80(1):65-73. doi: 10.1016/j.jad.2003.08.004. PMID: 15094259.

106. Yazici E, Kirkan TS, Aslan PA, Aydin N, Yazici AB. Untreated depression in the first trimester of pregnancy leads to postpartum depression: high rates from a natural follow-up study.

Neuropsychiatr Dis Treat. 2015 Feb 19;11:405-11. doi: 10.2147/NDT.S77194. PMID: 25737636 ; PMCID: PMC4344179.

107.Dubber S, Reck C, Müller M, Gawlik S. Postpartum bonding: the role of perinatal depression, anxiety and maternal-fetal bonding during pregnancy. Arch Womens Ment Health. 2015 Apr;18(2):187-195. doi: 10.1007/s00737-014-0445-4. Epub 2014 Aug 5. PMID: 25088531.

108. Molyneaux E, Telesia LA, Henshaw C, Boath E, Bradley E, Howard LM. Antidepressants for preventing postnatal depression. Cochrane Database Syst Rev. 2018 Apr 18;4(4):CD004363. doi: 10.1002/14651858.CD004363.pub3. PMID: 29669175; PMCID: PMC6494522.

109.Paulson JF, Bazemore SD. Prenatal and postpartum depression in fathers and its association with maternal depression: a meta-analysis. JAMA. 2010 May 19;303(19):1961-9. doi: 10.1001/jama.2010.605. PMID: 20483973.

110.Tirumalaraju V, Suchting R, Evans J, Goetzl L, Refuerzo J, Neumann A, Anand D, Ravikumar R, Green CE, Cowen PJ, Selvaraj S. Risk of Depression in the Adolescent and Adult Offspring of Mothers With Perinatal Depression: A Systematic Review and Meta-analysis. JAMA Netw Open. 2020 Jun 1;3(6):e208783. doi: 10.1001/jamanetworkopen.2020.8783. PMID: 32602910; PMCID: PMC7327545.

111. World Health Organization. Maternal mental health [Internet] [cited 2020 Sep 18]. Available from: https://www.who.int/mental_health/maternal-child/maternal_mental_health/en/

112. National Board of Health and Welfare. The Swedish Medical Birth Register-a summary of content and quality (2003). C.f. Epidemiology, Editor. 2003.

113. Wettermark B, Hammar N, Fored CM, Leimanis A, Otterblad Olausson P, Bergman U, et al. The new Swedish Prescribed Drug Register-opportunities for pharmacoepidemiological research and experience from the first six months. Pharmacoepidemiol Drug Saf 2007; 16: 726-35. doi: $10.1002 /$ pds. 1294 .

114. National Board of Health and Welfare. Coding Quality in the Patient Register, Slutenvård 2008 (in Swedish). Centre for Epidemiology, 2010. 
115.Ludvigsson JF, Andersson E, Ekbom A, Feychting M, Kim JL, Reuterwall C, Heurgren M, Olausson PO. External review and validation of the Swedish national inpatient register. BMC Public Health. 2011 Jun 9;11:450. doi: 10.1186/1471-2458-11-450. PMID: 21658213; PMCID: PMC3142234. (b)

116.Ludvigsson JF, Almqvist C, Bonamy, A-K E, Ljung, R, Michaëlsson K, Neovius M, et al. Registers of the Swedish total population and their use in medical research. European Journal of Epidemiology. 2016; 31(2), 125-136.

117.Horne R., Weinman J., Hankins M. The beliefs about medicines questionnaire: the development and evaluation of a new method for assessing the cognitive representation of medication.

Psychol. Health.1999;14:1-24.

118.Jörgensen TM, Andersson KA, Mårdby AC. Beliefs about medicines among Swedish pharmacy employees. Pharm World Sci. 2006 Aug;28(4):233-8. doi: 10.1007/s11096-005-2907-2. Epub 2006 May 11. PMID: 16691361.

119.Emilsson M, Berndtsson I, Gustafsson PA, Horne R, Marteinsdottir I. Reliability and validation of Swedish translation of Beliefs about Medication Specific (BMQ-Specific) and Brief Illness Perception Questionnaire (B-IPQ) for use in adolescents with attention-deficit hyperactivity disorder. Nord J Psychiatry. 2020 Feb;74(2):89-95. doi: 10.1080/08039488.2019.1674376. Epub 2019 Oct 9. PMID: 31596161.

120. Sturgis P, Roberts C, Smith P. Middle Alternatives Revisited: How the neither/nor Response Acts as a Way of Saying "I Don't Know"? Sociological Methods \& Research. 2014;43(1):15-38. doi:10.1177/0049124112452527

121. Boesl U. Time-of-flight mass spectrometry: Introduction to the basics. Mass Spectrom Rev. 2017 Jan;36(1):86-109. doi: 10.1002/mas.21520. Epub 2016 Nov 9. PMID: 27859457.

122. Marsal K, Persson PH, Larsen T, Lilja H, Selbing A, Sultan B. Intrauterine growth curves based on ultrasonically estimated foetal weights. Acta Paediatr. 1996;85:843-848. doi: 10.1111/j.16512227.1996.tb14164.x

123. Nyman U, Grubb A, Lindström V, Björk J. Accuracy of GFR estimating equations in a large Swedish cohort: implications for radiologists in daily routine and research. Acta Radiol. 2017;58(3):367-375. doi:10.1177/0284185116646143

124. Setia MS. Methodology Series Module 9: Designing Questionnaires and Clinical Record Forms - Part II. Indian J Dermatol. 2017 May-Jun;62(3):258-261. doi: 10.4103/ijd.IJD_200_17. PMID: 28584367; PMCID: PMC5448259.

125.Rockenbauer M, Olsen J, Czeizel AE, Pedersen L, Sørensen HT; EuroMAP Group. Recall bias in a case-control surveillance system on the use of medicine during pregnancy. Epidemiology. 2001 Jul;12(4):461-6. doi: 10.1097/00001648-200107000-00017. PMID: 11416783.

126. Grzeskowiak LE, Gilbert AL, Morrison JL. Investigating outcomes associated with medication use during pregnancy: a review of methodological challenges and observational study designs. Reprod Toxicol. 2012 Jun;33(3):280-9. doi: 10.1016/j.reprotox.2012.01.006. Epub 2012 Feb 4. PMID: 22329969. (a)

127. Cull WL, O'Connor KG, Sharp S, Tang SF. Response rates and response bias for 50 surveys of pediatricians. Health Serv Res. 2005 Feb;40(1):213-26. doi: 10.1111/j.1475-6773.2005.00350.x. PMID: 15663710; PMCID: PMC1361134.

128. Halbesleben JR, Whitman MV. Evaluating survey quality in health services research: a decision framework for assessing nonresponse bias. Health Serv Res. 2013 Jun;48(3):913-30. doi: 10.1111/1475-6773.12002. Epub 2012 Oct 10. PMID: 23046097; PMCID: PMC3681236.

129.Phillips AW, Reddy S, Durning SJ. Improving response rates and evaluating nonresponse bias in surveys: AMEE Guide No. 102. Med Teach. 2016;38(3):217-28. doi: 10.3109/0142159X.2015.1105945. Epub 2015 Dec 9. PMID: 26648511.

130.Draugalis JR, Coons SJ, Plaza CM. Best practices for survey research reports: a synopsis for authors and reviewers. Am J Pharm Educ. 2008 Feb 15;72(1):11. doi: 10.5688/aj720111. PMID: 18322573; PMCID: PMC2254236.

131.Johnson TP, Wislar JS. Response rates and nonresponse errors in surveys. JAMA. 2012 May 2;307(17):1805-6. doi: 10.1001/jama.2012.3532. PMID: 22550194.

132. Olesen C, Søndergaard C, Thrane N, Nielsen GL, de Jong-van den Berg L, Olsen J; EuroMAP Group. Do pregnant women report use of dispensed medications? Epidemiology. 2001 Sep;12(5):497-501. doi: 10.1097/00001648-200109000-00006. PMID: 11505166. 
133. Stephansson O, Granath F, Svensson T, Haglund B, Ekbom A, Kieler H. Drug use during pregnancy in Sweden - assessed by the Prescribed Drug Register and the Medical Birth Register. Clin Epidemiol. 2011 Feb 1;3:43-50. doi: 10.2147/CLEP.S16305. PMID: 21386973; PMCID: PMC3046184.

134. Messerlian C, Basso O. Cohort studies in the context of obstetric and gynecologic research: a methodologic overview. Acta Obstet Gynecol Scand. 2018 Apr;97(4):371-379. doi: 10.1111/aogs.13272. Epub 2017 Dec 26. PMID: 29194569.

135.Irl C, Hasford J. Assessing the safety of drugs in pregnancy: the role of prospective cohort studies. Drug Saf. 2000 Mar;22(3):169-77. doi: 10.2165/00002018-200022030-00001. PMID: 10738841 .

136. Källén B, Nilsson E, Olausson PO. Antidepressant use during pregnancy: comparison of data obtained from a prescription register and from antenatal care records. Eur J Clin Pharmacol. 2011 Aug;67(8):839-45. doi: 10.1007/s00228-011-1021-8. Epub 2011 Mar 9. PMID: 21387167.

137. Grzeskowiak LE, Gilbert AL, Morrison JL. Exposed or not exposed? Exploring exposure classification in studies using administrative data to investigate outcomes following medication use during pregnancy. Eur J Clin Pharmacol. 2012 May;68(5):459-67. doi: 10.1007/s00228-0111154-9. Epub 2011 Nov 13. PMID: 22080182.

138. Verster JC, van de Loo AJ, Adams S, Stock AK, Benson S, Scholey A, Alford C, Bruce G. Advantages and Limitations of Naturalistic Study Designs and their Implementation in Alcohol Hangover Research. J Clin Med. 2019 Dec 6;8(12):2160. doi: 10.3390/jcm8122160. PMID: 31817752 ; PMCID: PMC6947227.

139. van Gelder MMHJ, de Jong LAA, Te Winkel B, Olyslager EJH, Vorstenbosch S, van Puijenbroek EP, Verbeek ALM, Roeleveld N. Assessment of medication use during pregnancy by Web-based questionnaires, pharmacy records and serum screening. Reprod Toxicol. 2019 Mar;84:93-97. doi: 10.1016/j.reprotox.2019.01.002. Epub 2019 Jan 4. PMID: 30615926.

140.HendrickV, Stowe ZN, Altshuler LL, Hwang S, Lee E, Haynes D. Placental passage of antidepressant medications. Am J Psychiatry, 2003. 160(5): p. 993-6.

141. Hostetter A, Ritchie JC, Stowe ZN, Amniotic fluid and umbilical cord blood concentrations of antidepressants in three women. Biol Psychiatry, 2000. 48(10): p. 1032-4.

142.Paulzen M, Schoretsanitis G, Gründer G, Franz C, Stingl JC, Augustin M. Pregnancy exposure to venlafaxine-Therapeutic drug monitoring in maternal blood, amniotic fluid and umbilical cord blood and obstetrical outcomes. J Affect Disord. 2020;266:578-584. doi:10.1016/j.jad.2020.02.010

143.Paulzen M, Goecke TW, Stingl JC, Janssen G, Stickeler E, Gründer G, Schoretsanitis G. Pregnancy exposure to citalopram - Therapeutic drug monitoring in maternal blood, amniotic fluid and cord blood. Prog Neuropsychopharmacol Biol Psychiatry. 2017 Oct 3;79(Pt B):213219. doi: 10.1016/j.pnpbp.2017.06.030. Epub 2017 Jun 27. PMID: 28663113.

144.Paulzen M, Goecke TW, Stickeler E, Gründer G, Schoretsanitis G. Sertraline in pregnancy Therapeutic drug monitoring in maternal blood, amniotic fluid and cord blood. J Affect Disord, 2017. 212: p. 1-6.

145. Rampono J, Simmer K, Ilett KF, Hackett LP, Doherty DA, Elliot R et al. Placental transfer of SSRI and SNRI antidepressants and effects on the neonate. Pharmacopsychiatry, 2009. 42(3): p. 95-100.

146.Sit D, Perel JM, Wisniewski SR, Helsel JC, Luther JF, Wisner KL. Mother-infant antidepressant concentrations, maternal depression, and perinatal events. J Clin Psychiatry, 2011. 72(7): p. 9941001 .

147.Akselsson A, Lindgren H, Georgsson S, Pettersson K, Skokic V, Rådestad I. Pregnancy outcomes among women born in Somalia and Sweden giving birth in the Stockholm area - a population-based study. Glob Health Action. 2020 Dec 31;13(1):1794107. doi: 10.1080/16549716.2020.1794107. PMID: 32744184; PMCID: PMC7480426.

148.Vik ES, Aasheim V, Schytt E, Small R, Moster D, Nilsen RM. Stillbirth in relation to maternal country of birth and other migration related factors: a population-based study in Norway. BMC Pregnancy Childbirth. 2019 Jan 5;19(1):5. doi: 10.1186/s12884-018-2140-3. PMID: 30611227; PMCID: PMC6321699. 


\section{ERRATA}

\section{Paper 1}

\begin{tabular}{|l|l|l|}
\hline Page & Original text & Correction \\
\hline 4, right column & $\begin{array}{l}\text { However, pregnant women } \\
\text { who had a low educational } \\
\text { level perceived herbal } \\
\text { medicines to be harmful or } \\
\text { probably } \\
\text { harmful during pregnancy } \\
\text { and breastfeeding in } \\
\text { contrast to women } \\
\text { with intermediate and high } \\
\text { educational level. }\end{array}$ & $\begin{array}{l}\text { Howere pregnant women } \\
\text { who had perceived herbal } \\
\text { level } \\
\text { medicines to be harmful or } \\
\text { probably } \\
\text { harmful during pregnancy } \\
\text { and breastfeeding to a } \\
\text { lesser extent compared } \\
\text { with women } \\
\text { with intermediate and high } \\
\text { educational level. }\end{array}$ \\
\hline Page 6, Figure 1 & $\begin{array}{l}\text { Significances should also } \\
\text { be on later pregnancy and } \\
\text { breastfeeding. }\end{array}$ \\
\hline Page 7, Figure 2 & $\begin{array}{l}\text { The colour explanation } \\
\text { should be in reverse order } \\
\text { (left } \rightarrow \text { right): Harmless, } \\
\text { Probably harmless, } \\
\text { Probably harmful, } \\
\text { Harmful }\end{array}$ \\
\hline
\end{tabular}


APPENDIX 


\section{Gravida kvinnors uppfattning om läkemedel}

När du besvarar följande frågor, som rör dina uppfattningar om läkemedelsanvändning under graviditet, vill vi göra dig uppmärksam på att inget svar är mer rätt eller fel än ett annat svar. Vi är intresserade av dina personliga uppfattningar.

1. Vad anser du om läkemedelsanvändning under tidig graviditet (de tre första månaderna)?

2. Vad anser du om läkemedelsanvändning senare under graviditeten (efter tredje månanden)?

3. Vad anser du om användning av Paracetamol (ex Alvedon/Panodil) under graviditet?

4. Vad anser du om användning av läkemedel mot depression under graviditet?

5. Vad anser du om användning av läkemedel mot

halsbränna/magkatarr under graviditet?

6. Vad anser du om användning av läkemedel mot graviditetsillamående?

7. Vad anser du om användning av läkemedel mot astma/allergi under graviditet?

8. Vad anser du om antibiotikaanvändning under graviditet?

9. Vad anser du om läkemedelsanvändning under amning och dess påverkan på barnet?

10. Vad anser du om naturläkemedelsanvändning under tidig graviditet (de tre första månaderna)?

Ofarligt $\begin{gathered}\text { Troligen } \\ \text { ofarligt }\end{gathered} \quad \begin{gathered}\text { Trolige } \\ \text { skadligt }\end{gathered}$

\section{Skadligt} kadligt

(1)




\section{Ofarligt $\begin{gathered}\text { Troligen } \\ \text { ofarligt }\end{gathered} \quad \begin{gathered}\text { Troligen } \\ \text { skadligt }\end{gathered}$ Skadligt}

11. Vad anser du om naturläkemedelsanvändning

senare under graviditeten (efter tredje månanden)?

12. Vad anser du om naturläkemedelsanvändning under amning och dess påverkan på barnet?

13. Om du skulle använda läkemedel under graviditeten hur orolig skulle du vara för följande;
Inte orolig
Lite orolig
Ganska orolig
Mycket orolig

a. Missbildningar hos

barnet?

b. Mental påverkan hos barnet?

c. Att barnet ska vara tillväxthämmat?

d. Att barnet ska

födas för tidigt?

e. Att risken för komplicerad graviditet ska öka?

f. Att risken för

komplicerad

förlossning ska öka?

Nedan följer ett antal påståenden som vi vill att du tar ställning till.

Om du håller med om båda påståendena lika mycket sätter du krysset i mitten. Om du helt håller med om påståendet till vänster sätter du krysset i rutan längst till vänster. Om du delvis håller med om påståendet till vänster sätter du krysset i rutan näst längst till vänster. Om du helt håller med om påståendet till höger sätter du krysset längst till höger. Om du delvis håller med om påståendet till höger sätter du krysset näst längst till höger. Du ska bara fylla i ett kryss per rad.

\begin{tabular}{|c|c|c|c|c|}
\hline $\begin{array}{c}\text { Håller } \\
\text { helt med }\end{array}$ & $\begin{array}{c}\text { Håller } \\
\text { delvis } \\
\text { med }\end{array}$ & $\begin{array}{l}\text { Håller med } \\
\text { båda } \\
\text { påstående } \\
\text { lika } \\
\text { mycket }\end{array}$ & $\begin{array}{c}\text { Håller } \\
\text { delvis } \\
\text { med }\end{array}$ & $\begin{array}{c}\text { Håller } \\
\text { helt } \\
\text { med }\end{array}$ \\
\hline
\end{tabular}

14. Gravida kvinnor skall undvika alla former av läkemedel

Gravida kvinnor kan utan problem använda alla former av läkemedel 


\begin{tabular}{|c|c|c|c|c|}
\hline $\begin{array}{l}\text { Håller } \\
\text { helt med }\end{array}$ & $\begin{array}{c}\text { Håller } \\
\text { delvis } \\
\text { med }\end{array}$ & $\begin{array}{l}\text { Håller med } \\
\text { båda } \\
\text { påstående } \\
\text { lika } \\
\text { mycket }\end{array}$ & $\begin{array}{c}\text { Håller } \\
\text { delvis } \\
\text { med }\end{array}$ & $\begin{array}{c}\text { Håller } \\
\text { helt } \\
\text { med }\end{array}$ \\
\hline
\end{tabular}

15. Läkemedelsanvändning under graviditet gör mer skada än nytta

16. Kvinnans hälsa kommer $i$ första hand när det gäller läkemedelsanvändning under graviditet

17. Om jag skulle få ett läkemedel förskrivet under graviditen skulle jag följa behandlingen

18. Jag är mer benägen att använda läkemedel när jag är gravid än när jag inte är gravid

19. Tack vare läkemedelsbehandling under graviditet kan många barns liv räddas

Nyttan med

läkemedelsanvändning under graviditet uppväger riskerna

Fostrets hälsa kommer i första hand när det gäller läkemedelsanvändning under graviditet

Om jag skulle få ett läkemedel förskrivet under graviditeten skulle jag inte följa behandlingen

Jag har större motstånd att använda läkemedel när jag är gravid än när jag inte är gravid

Läkemedelsbehandling under graviditet ökar risken för missfall

20. Har du något ytterligare du skulle vilja dela med dig av när det gäller din uppfattning kring läkemedelsbehandling och graviditet? 
21. Var skulle du vända dig om du har frågor eller funderingar om läkemedelsanvändning under din graviditet?

a. Barnmorska på Mödrahälsovård, förlossning eller BB

b. Läkare på Mödrahälsovård, förlossning eller BB

c. Läkare (någon annanstans än ovan)

d. Apotek

e. Bipacksedeln i läkemedelsförpackningen

f. FASS.se (läkemedelsinformation)

g. 1177.se (vårdguide)

h. Janusinfo.se (läkemedelsinformation)

i. Olika forumsidor som ex Familjeliv

j. Vänner/släktingar

22. Om du skulle behöva använda läkemedel under din graviditet vilket förtroende har du för råd från
a. Barnmorska på Mödrahälsovård, förlossning eller BB
b. Läkare på Mödrahälsovård, förlossning eller BB
c. Läkare (någon annanstans än ovan)
d. Vänner/släktingar

Nedan följer ett antal frågor om dig och din graviditet

23. Hur gammal är du?
$\square \leq 19$ år
$\square$ 20-29 år
$\square$ 30-39 år
$\square \geq 40$ år

24. Väntar du ditt första barn?

\begin{tabular}{|c|c|c|c|}
\hline $\begin{array}{c}\text { Skulle } \\
\text { troligen } \\
\text { vända mig } \\
\text { till }\end{array}$ & $\begin{array}{c}\text { Skulle } \\
\text { kanske } \\
\text { vända } \\
\text { mig till }\end{array}$ & $\begin{array}{c}\text { Skulle inte } \\
\text { vända mig } \\
\text { till }\end{array}$ & $\begin{array}{c}\text { Känner inte } \\
\text { till } \\
\text { informations } \\
\text { källan }\end{array}$ \\
\hline
\end{tabular}

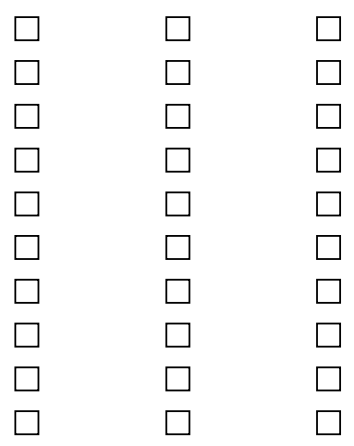

$\square$

$\begin{array}{cccc}\begin{array}{c}\text { Stort } \\ \text { förtroende }\end{array} & \begin{array}{c}\text { Ganska } \\ \text { stort } \\ \text { förtroende }\end{array} & \begin{array}{c}\text { Ganska } \\ \text { litet } \\ \text { förtroende }\end{array} & \begin{array}{c}\text { Litet } \\ \text { förtroende }\end{array}\end{array}$

förtroende förtroende
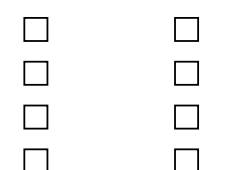
25. Vilken är din högsta avslutade utbildning?

$\square$ Grundskola

$\square$ Gymnasieskola

$\square$ Högskola/universitet

26. Har du ändrat uppfattning om

läkemedelsanvändning under graviditet sedan du själv blev gravid?

$\square$ Ja

$\square \mathrm{Nej}$

27. Hur ofta har du använt läkemedel under din nuvarande graviditet?

$\square$ Varje dag

$\square$ Flera ggr/vecka

$\square$ Ngn gång/vecka

$\square$ Ngn gång/månad

$\square$ Mer sällan eller aldrig

28. Har du hittills haft behov eller använt läkemedel för följande tillstånd under din nuvarande graviditet?
a. Astma/allergi
b. Graviditetsillamående

c. Smärttillstånd där jag använt Paracetamol (ex. Panodil, Alvedon)

d. Halsbränna/magkatarr

e. Sjukdom där läkemedelsbehandling är nödvändig eller starkt rekommenderad (ex. diabetes, epilepsi,

sköldkörtelsjukdom, reumatisk sjukdom, infektionssjukdom, tarmsjukdom, högt blodtryck)

f. Kroniska smärtor (ex. fibromyalgi, Ehlers- Danlos sjukdom)

g. Depression

$+$

\section{Haft behov Haft behov och \\ men avstått använt läkemedel från}

läkemedel behov av

läkemedel 


\section{Inte haft Haft behov Haft behov och \\ behov av men avstått använt läkemedel \\ läkemedel från}

läkemedel

h. Huvudvärk eller migrän

i. Antibiotika mot akut infektion (ex urinvägsinfektion, halsfluss)

j. Annat:

k. Annat:

Om du, efter att ha besvarat enkäten, har frågor rörande läkemedelsbehandling och graviditet rekommenderar vi att du i första hand kontaktar din barnmorska på Mödrahälsovården

\section{Tack för din medverkan!}




\section{Papers}

The papers associated with this thesis have been removed for copyright reasons. For more details about these see:

http://urn.kb.se/resolve?urn=urn:nbn:se:liu:diva-171515 


\section{FACULTY OF MEDICINEAND HEALTH SCIENCES}

linkoping University Medical Dissertation No. 1763, 2020

Department of Biomedical and clinical Sciences

Linkoping university

SE-58183 Linkoping, Sweden

whiliuse

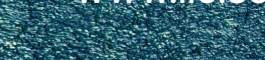

